\title{
The influence of inherited continental margin structures on the stress and strain fields of the south-central Taiwan fold-and-thrust belt
}

\author{
Cristina Biete ${ }^{\oplus}, 1,2$ Dennis Brown, ${ }^{1,3}$ Björn Lund, ${ }^{4}$ Joaquina Alvarez-Marron, ${ }^{1}$ \\ Yih-Min $\mathrm{Wu},{ }^{5,6,7}$ Hao Kuo-Chen ${ }^{\oplus 3}$ and Chun-Wei $\mathrm{Ho}^{3,8}$ \\ ${ }^{1}$ Institute of Earth Sciences, Jaume Almera, ICTJA, CSIC, Lluis Sole i Sabaris s/n, 08028 Barcelona, Spain. E-mail: cristina.biete@gmail.com \\ ${ }^{2}$ Departament de Dinàmica de la Terra i de l'Oceà, Universitat de Barcelona, 02028 Barcelona, Spain \\ ${ }^{3}$ Department of Earth Science, National Central University, Zhongli District, 32001 Taoyuan City, Taiwan \\ ${ }^{4}$ Department of Earth Sciences, Uppsala University, 75236 Uppsala, Sweden \\ ${ }^{5}$ Department of Geosciences, National Taiwan University, 10617 Taipei, Taiwan \\ ${ }^{6}$ Institute of Earth Sciences, Academia Sinica, 11529 Taipei, Taiwan \\ ${ }^{7}$ NTU Research Center for Future Earth, National Taiwan University, 10617 Taipei, Taiwan \\ ${ }^{8}$ Central Weather Bureau, 10048 Taipei, Taiwan
}

Accepted 2019 June 25. Received 2019 June 7; in original form 2018 November 7

\begin{abstract}
SUMMAR Y
In this paper we test whether or not structural and morphological features inherited from the Eurasian continental margin are affecting the contemporary stress and strain fields in southcentral Taiwan. Principal stress directions $\left(\sigma_{1}, \sigma_{2}\right.$ and $\left.\sigma_{3}\right)$ are estimated from the inversion of clustered earthquake focal mechanisms and the direction of the maximum compressive horizontal stress $\left(S_{\mathrm{H}}\right)$ is calculated throughout the study area. From these data the most likely fault plane orientations and their kinematics are inferred. The results of the stress inversion are then discussed together with the directions of displacement, compressional strain rate and maximum shear strain rate derived from GPS data. These data show that there is a marked contrast in the direction of $S_{\mathrm{H}}$ from north to south across the study area, with the direction of $S_{\mathrm{H}}$ remaining roughly subparallel to the relative plate motion vector in the north, whereas in the south it rotates nearly $45^{\circ}$ counter-clockwise. The direction of the horizontal maximum compression strain rate $\left(\varepsilon_{\mathrm{H}}\right)$ and associated maximum shear planes, together with the displacement field display an overall similar pattern between them, although undergoing a less marked rotation. We interpret the southward change in the $S_{\mathrm{H}}, \varepsilon_{\mathrm{H}}$ and the dextral maximum shear plane directions, together with that of the horizontal displacement field to be related to the reactivation of east-northeast striking faults inherited from the rifted Eurasian margin and to the shelf/slope break. Inherited faults in the basement are typically reactivated as strike-slip faults, whereas newly formed faults in the fold-and-thrust belt are commonly thrusts or oblique thrusts. Eastwards, the stress inversions and strain data show that the western flank of the Central Range is undergoing extension in the upper crust. $S_{\mathrm{H}}$ in the Central Range is roughly parallel to the relative plate convergence vector, but in southwestern Taiwan it undergoes a marked counter-clockwise rotation westwards across the Chaochou fault. Farther north, however, there is no significant change across the Lishan fault. This north to south difference is likely due to different margin structures, although local topographic effects may also play a role.
\end{abstract}

Key words: Asia; Seismicity and tectonics; Crustal structure; Dynamics: seismotectonics; Dynamics and mechanics of faulting.

\section{INTRODUCTION}

The determination of the stress and strain fields in a fold-and-thrust belt is important because these are necessary parameters for the understanding of its mechanic, geometric and kinematic evolution (e.g. Angelier et al. 1986; Oncken 1988; Erslev 1993; Becker 2000; Homberg et al. 2002; Saintot \& Angelier 2002; Lacombe et al. 2006; King et al. 2009; Peyret et al. 2011; Tavani et al. 2015). For example, based on studies in both active and fossil fold-and-thrust belts, Tavani et al. (2015) concluded that, although the stress and 
strain fields can be locally complex, even during syn-thrusting a strike-slip stress field is the most common. While they suggest that this conclusion is perhaps somewhat counterintuitive, they interpret it to result from the reactivation of inherited structures. Célérier (2008) proposed that the reactivation of faults with near-optimal orientations (e.g. Sibson, 1990, 1994; Kelly et al. 1999; Leclère \& Fabbri 2013) controls the state of stress in the crust. Knowledge of the stress and strain fields can, therefore, play an important part in a data set aimed at deciphering the role of reactivation of inherited structures in the development of a fold-and-thrust belt.

With this in mind, in this paper we continue to explore the possible effects that the morphology and inherited structures of the Eurasian continental margin are having on the fold-and-thrust belt in southcentral Taiwan (Fig. 1), which we have investigated in a series of recent publications (Brown et al. 2012, 2017; Alvarez-Marron et al. 2014; Camanni et al. 2014, 2016; Biete et al. 2018). In these studies, we used seismicity data, $P$-wave velocity models and geodetic data, together with geometric analyses of surface and subsurface geological structures to propose that there is a causal link between along-strike changes in these features and the reactivation of fault systems inherited from the margin's outer shelf and necking zone. Here, we investigate this proposal further by estimating the principal stress directions $\left(\sigma_{1}, \sigma_{2}\right.$ and $\left.\sigma_{3}\right)$ using inversion of clustered earthquake focal mechanisms and calculating the direction of maximum compressive horizontal stress $\left(S_{\mathrm{H}}\right)$ throughout the fold-and-thrust belt in the study area. From these data we then determine the fault planes that are likely to have been activated at depth. We discuss the combined results of the stress inversions with the directions of displacement, and the compressional, rotational and maximum shear strain rates derived from the GPS data. The hypothesis to be tested is whether or not the previously proposed causal link between the inherited features of the margin and the structure of the fold-andthrust belt is supported by the contemporary stress and strain fields in south-central Taiwan.

\section{GEOLOGICAL SETTING}

\subsection{Eurasian continental margin}

The continental margin of Eurasia that is involved in the Taiwan fold-and-thrust belt evolved from a subcontinental subduction system in the Late Cretaceous ( $\mathrm{Li}$ et al. 2007; Lan et al. 2008) to a rifting margin by the Early Eocene, with seafloor spreading starting in the South China Sea by the late Early Oligocene (e.g. Briais et al. 1993). Beginning in the Early Miocene several extensional events further affected the outer margin (e.g. Lin et al. 2003). Throughout this paper, we follow the scheme of Alvarez-Marron et al. (2014) and Brown et al. (2017), when describing the geology of the continental margin, defining the pre-Eocene rift-related rocks as its basement, the area of basement thinning towards the South China Sea ocean basin as the necking zone (see Mohn et al. 2012 for a definition of necking zone) and the slope as the morphological feature where the sediments were deposited on the necking zone. Today's shelf/slope break is defined as the $200 \mathrm{~m}$ bathymetry contour (Fig. 1).

During the Eocene rifting, several roughly northeast trending basins (e.g. the Taishi and Nanjihtao basins) developed and were filled with up to $5 \mathrm{~km}$ of sediment (Hsu et al. 2001; Lin \& Watts 2002; Lin et al. 2008; Huang et al. 2012; Yeh et al. 2012; Fig. 1). The Taihsi Basin is thought to extend eastwards into the Taiwan mountain belt where it is now exposed in the Hsuehshan Range (HR; Fig. 1; Teng 1992; Teng \& Lin 2004). The Miocene extension resulted in the formation of a number of east-northeast striking extensional faults (B fault, Yichu fault, etc., Fig. 1) and the formation of the Tainan Basin on the necking zone of the margin (e.g. Yang et al. 1991; Lin \& Watts 2002; Lin et al. 2003; Ding et al. 2008). From north to south, the area of transition from the shelf to the necking zone is commonly called the Peikang High (Fig. 1). The Tainan Basin and the faults associated with it extend from the offshore southwestern Taiwan on land through the undeformed foreland and into the fold-and-trust belt (Fig. 1; e.g. Lin et al. 2003; RodriguezRoa \& Wiltschko 2010; Alvarez-Marron et al. 2014; Yang et al. 2016; Brown et al. 2017). Recently, Yeh et al. (2012), McIntosh et al. (2014) and Lester et al. (2014) identified what they interpreted to be a failed rift located at the base of the slope. Reflection seismic data show that it extends northeastwards along the base of the slope (McIntosh et al. 2014) and possibly into the southwestern part of the island (Brown et al. 2017; Biete et al. 2018). This failed rift marks the onset of the hyper-extended part of the margin, which extends for more than $200 \mathrm{~km}$ to the south (Lester et al. 2014). It is the reactivation of these Eocene and Miocene extensional faults that we have previously proposed to be having an important effect on the geometrical development of the fold-and-thrust belt, its seismicity and its topography (Brown et al. 2012, 2017; Alvarez-Marron et al. 2014; Camanni et al. 2014, 2016; Biete et al. 2018).

\subsection{South-central Taiwan fold-and-thrust belt}

Within the Taiwan mountain belt (Fig. 1), the study area is divided into several roughly $\mathrm{N}-\mathrm{S}$ striking tectono-stratigraphic units (e.g. Ho 1988) that, from west to east, are: the Coastal Plain (CP), the Western Foothills (WF), the Hsuehshan Range (HR) and the Central Range (CR). The Coastal Range (CoR) is outside the study area and will not be mentioned further. For the sake of simplicity, in this study we group the Coastal Plain, Western Foothills and Hsuehshan Range under the term fold-and-thrust belt, which is juxtaposed against the Central Range along the Lishan-Chaochou fault system (Fig. 2). While we have only limited structural data for the Central Range, we include its western flank in this study because of the important changes in the stress and strain fields that occur from west to east across the Lishan-Chaochou fault system (see Sections 3 and 4 below).

In this paper, we follow the structural interpretations of the foldand-thrust belt that have been proposed by Brown et al. (2012, 2017), Alvarez-Marron et al. (2014) and Biete et al. (2018). Within the study area, the fold-and-thrust belt has a roughly N-S structural grain that becomes more NE-SW in the southwestern part (Fig. 2). It is a west-verging imbricate thrust system developed above a basal thrust that dips overall eastwards from its tip line along the Changhua thrust in the west to a maximum depth of about $7 \mathrm{~km}$ before ramping down into the basement (Brown et al. 2012; Alvarez-Marron et al. 2014; Biete et al. 2018). A number of pronounced east-northeast striking lateral and oblique ramps have been interpreted to occur along the basal thrust over its north-south extent. This interpretation is based on along-strike changes in structure, seismicity, topography and $P$-wave velocity (e.g. Brown et al. 2017). Alvarez-Marron et al. (2014), Brown et al. (2017) and Biete et al. (2018) have proposed that these along-strike changes have a causal relationship with the extensional faults inherited from the continental margin. Along its eastern flank, the fold-and-thrust belt is juxtaposed against the Central Range along the oblique thrust to sinistral strike-slip Chaochou-Lishan fault system that extends along the entire length of the mountain belt and has been interpreted 


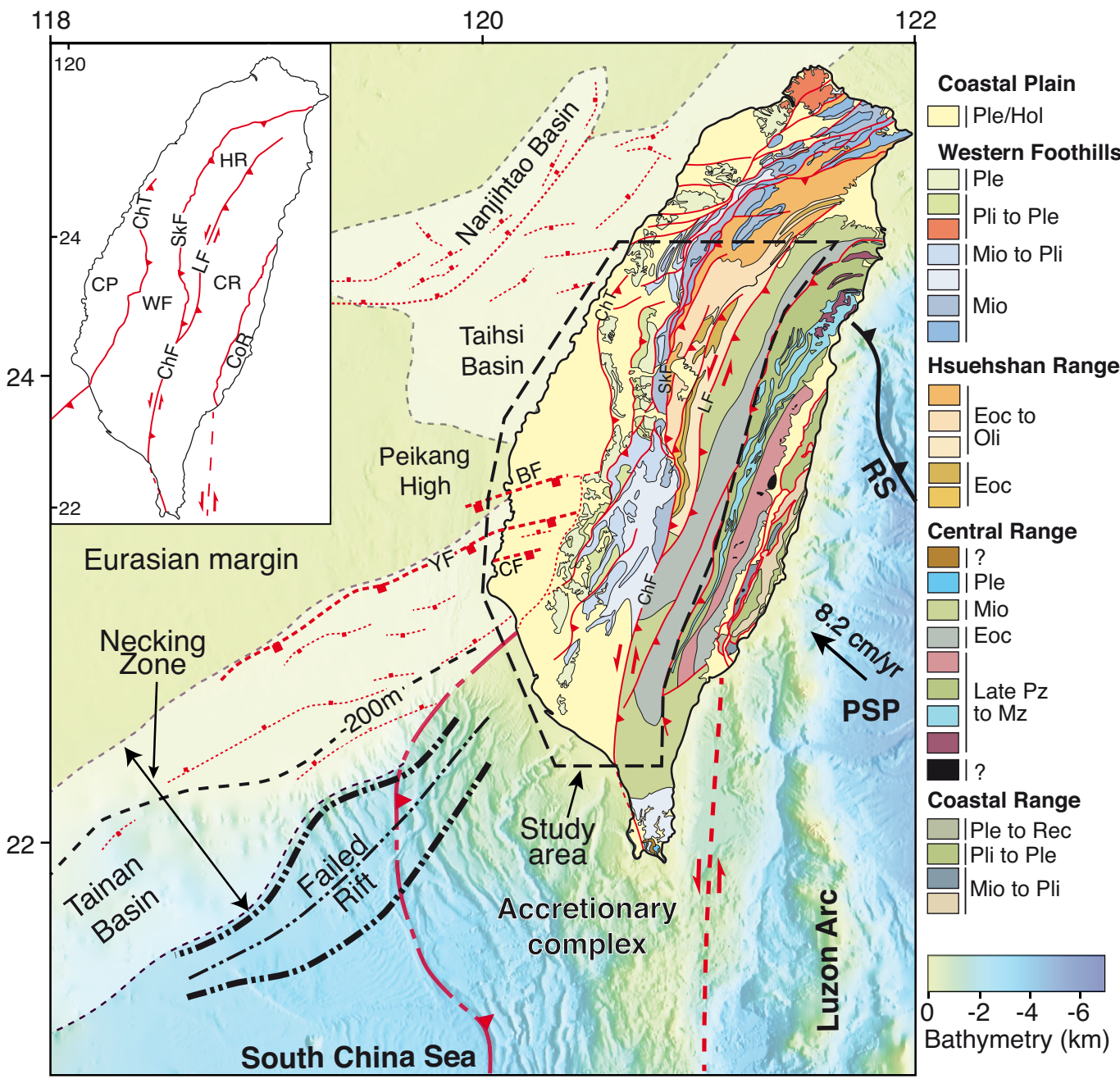

Figure 1. Tectonic setting of the Taiwan orogen. The geology of Taiwan is from Chen (2000) with our modifications. The inset shows the main tectonostratigraphic units discussed in the text. The structural (necking zone, failed rift, extensional basins and major faults) and morphological features (shelf/slope break at $200 \mathrm{~m}$ water depth) of the Eurasian continental margin are shown. The study area is highlighted by the black dashed line. The relative plate motion vector of $8.2 \mathrm{~cm} \mathrm{yr}^{-1}$ towards $306^{\circ}$ (Yu et al. 1997) between the Eurasian margin and the Philippine Sea Plate is given. RS, Ryukyu subduction zone; PSP, Philippine Sea Plate; ChT, Changhua thrust; LF, Lishan Fault; SkF, Shuilikeng Fault; ChF, Chauchou Fault; BF, B fault; YF, Yichu fault; CF, Chiali fault. The inset shows the tectono-stratigraphic units of the Taiwan orogen. CP, Coastal Plain; WF, Western Foothills; HR, Hsuehshan Range; CR, Central Range; CoR, Coastal Range.

to penetrate into the middle and even lower crust (Wiltschko et al. 2010; Tang et al. 2011; Huang \& Byrne 2014; Kuo-Chen et al. 2015; Figs 1 and 2). A geological description of the Central Range is out of the scope of this paper.

In the study area, much of the seismicity is located below the basal thrust of the fold-and-thrust belt, in the basement (e.g. Wang et al. 2000; Carena et al. 2002; Yue et al. 2005; Camanni et al. 2016; Brown et al. 2017), so knowing the depth to the top of the basement is important to our study (see Section 2.1. for our definition of basement). The exact depth to the top of the basement is not well known since it does not crop out in the study area and it has been intersected only in several boreholes in the Coastal Plain (e.g. Chiu 1975; Jahn et al. 1992; Shaw 1996). Therefore, we use a petrophyscial proxy to define its location. The rationale for this has been presented by Camanni et al. (2016) and Brown et al. (2017) and the reader is referred there for extensive discussions of it. We use a $P$-wave velocity of $5.2 \mathrm{~km} \mathrm{~s}^{-1}$ to describe the top of the basement (or, to view it another way, the base of the clastic sediments, whose maximum $P$-wave velocity is about $5.2 \mathrm{~km} \mathrm{~s}^{-1}$; Brocher 2005). Using this velocity description, the basement/cover interface is between 5 and $8 \mathrm{~km}$ depth throughout much of the study area, except beneath the Hsuehshan Range and along the eastern part of the fold-and-thrust belt between $23^{\circ} \mathrm{N}$ and $24^{\circ} \mathrm{N}$ (Fig. 3). East of the Chaochou-Lishan fault system the basement rocks approach the surface, and in fact crop out extensively in the Central Range, east of our study area.

\section{CONTEMPORANEOUS STRESS FIELD IN SOUTH-CENTRAL TAIWAN}

\subsection{Methodology}

In this study we use earthquake focal mechanisms to estimate the contemporaneous stress field in south-central Taiwan. The earthquakes were recorded between 1994 and 2014 and all hypocentres 


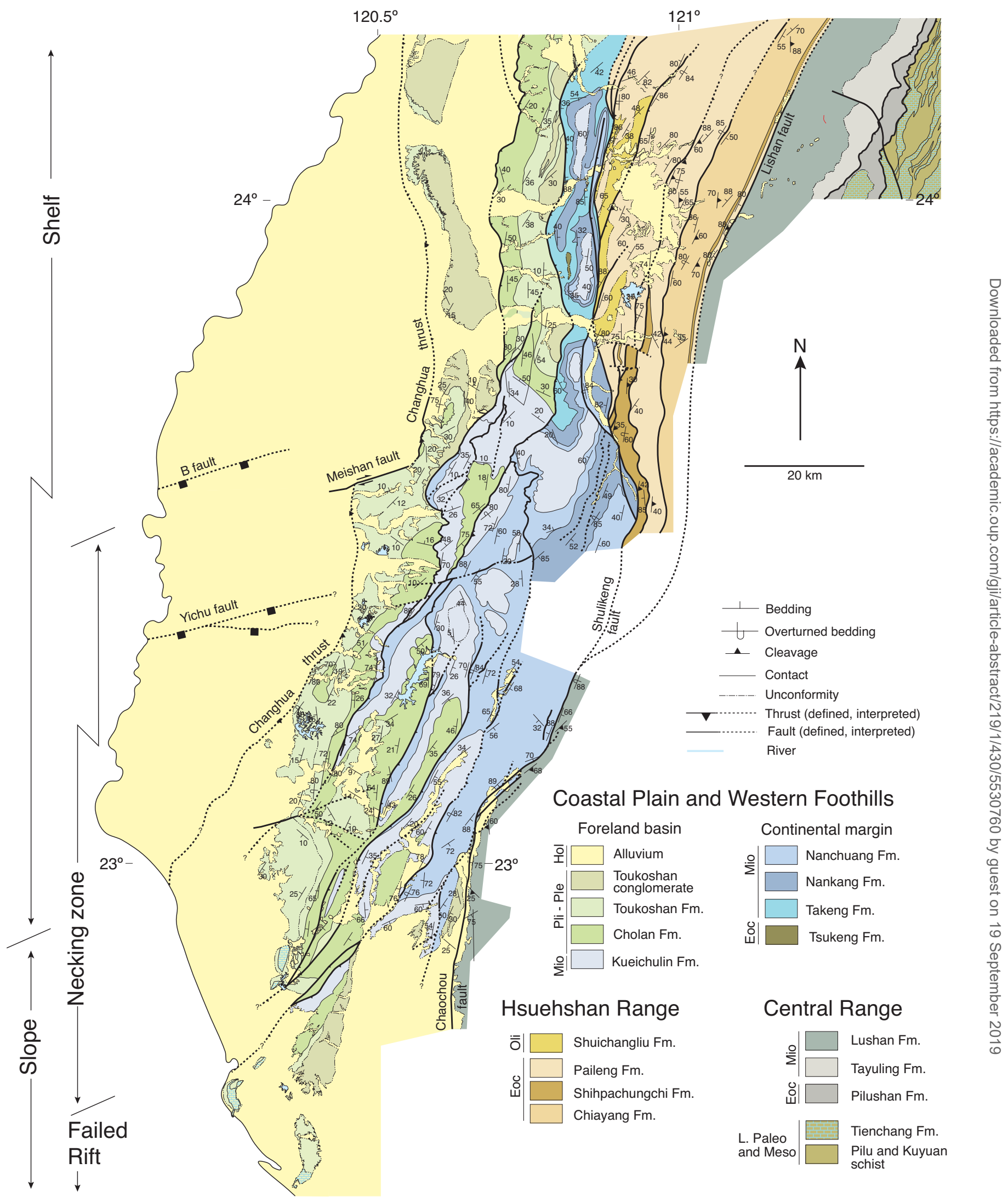

Figure 2. Geological map of the study area with representative structural data. The location of the main structural and morphological features of the Eurasian continental margin are shown. 


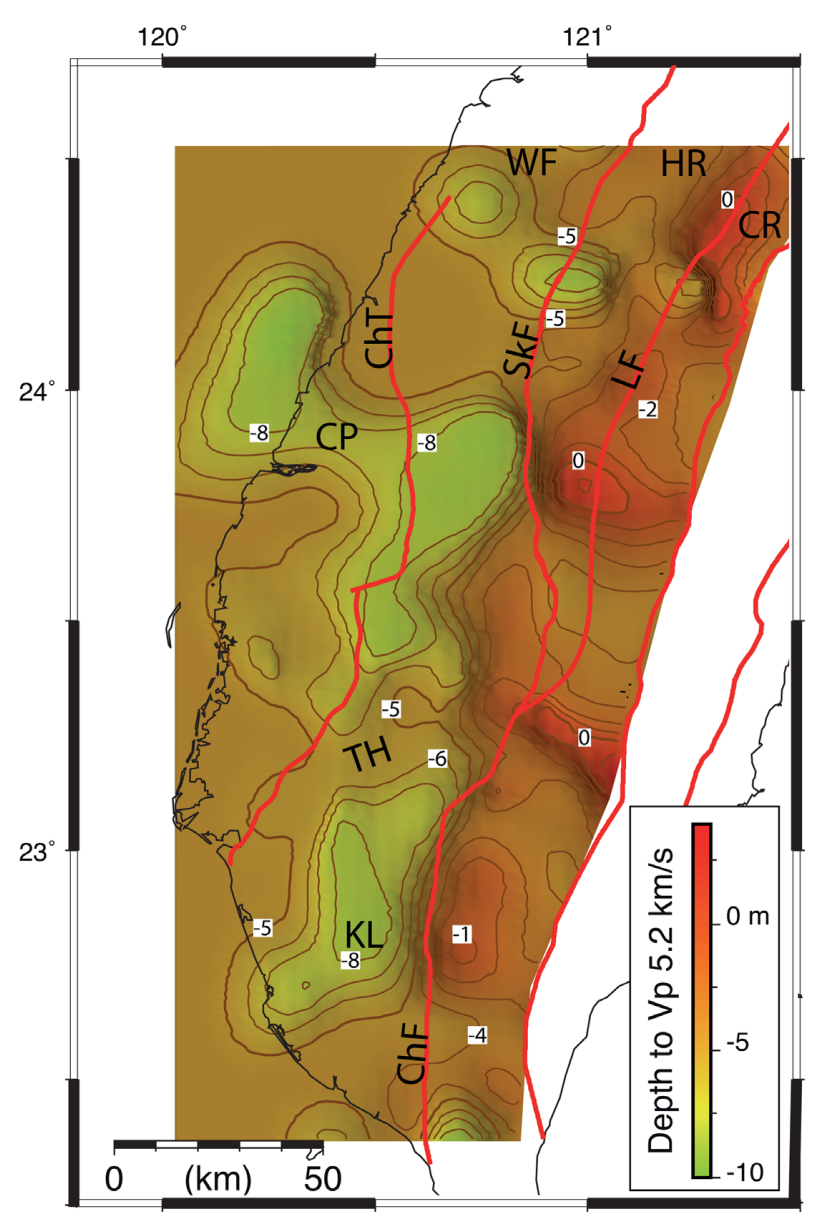

Figure 3. Map of the $5.2 \mathrm{~km} \mathrm{~s}^{-1}$ proxy for the depth to the top of the basement extracted from the 3-D tomographic model of Kuo-Chen et al. (2012). The Tainan basement high (TH) and the Kaoshiang basement low $(\mathrm{KL})$ are highlighted. Labels of faults and tectono-stratigraphic units are as in the inset of Fig. 1.

have been relocated by the double-difference technique (Waldhauser \& Ellsworth 2000) using the HypoDD3D software (Waldhauser 2001) within the 3-D $P$-wave velocity model of Kuo-Chen et al. (2012). The average horizontal uncertainties in earthquake locations are estimated to be $\pm 1 \mathrm{~km}$, while the vertical are $\pm 2 \mathrm{~km}$ (Brown et al. 2017). In this study we have used all events over the time period given, regardless of transitory stress changes caused by large events like the 1999 Chi-Chi earthquake. It is well known that large earthquakes can cause transitory changes in the stress field (e.g. Michael 1987; Hardebeck \& Hauksson 2001; Wu et al. 2010; Hensch et al. 2016; Hardebeck \& Okada 2018), but it is not well understood how long such a stress change can last (Hardebeck \& Okada 2018). For example, while there was a marked change in the stress field in parts of Taiwan following the $1999 M_{\mathrm{w}}$ 7.6 Chi-Chi earthquake, this change was spatially heterogeneous and took several months to more than a year to return to what it was prior to the earthquake (Wu et al. 2010; Hsu et al. 2011). Removing earthquake data during a period of time after the Chi-Chi event in order to take into account its effect on the contemporaneous stress field would, therefore, not be necessarily correct since the changes recorded and the time it took to return to what it was before are spatially heterogeneous. Furthermore, there have been a number of other large earthquakes in the study area, such as the $1998 M_{\mathrm{L}} 6.2$ Rueyli, the $1999 M_{\mathrm{L}} 6.4$ Chiayi and the $2010 M_{\mathrm{L}} 6.4$ Jiashian events, whose spatial and temporal effects on the contemporaneous stress field in western Taiwan have not been studied. Therefore, selectively removing a time period of data related to the large earthquakes would bias the data set in areas unaffected by them.

In this study we use a hypothesis driven approach (e.g. Hardebeck $\&$ Michael 2004) to do the binning of the focal mechanism data for the stress inversion. It is designed to test whether or not the preexisting structure of the margin is influencing the contemporaneous stress field. Since much of the seismicity of the study area occurs within the basement (Fig. 4), we have divided the crust into three depth levels. From 0 to $6.9 \mathrm{~km}$ comprises the fold-and-thrust belt and/or the sedimentary carapace overlying the basement. Some 37 per cent of earthquakes occur within this depth level (Fig. 4). From 7 to $45 \mathrm{~km}$ comprises the basement, which is divided into two depth levels. From 7 to $14.9 \mathrm{~km}$ contains 47 per cent of earthquakes and its base is chosen to coincide with the depth to the expected thermal cut-off for seismicity [about $350+100{ }^{\circ} \mathrm{C}$; Sibson (1983) and Chen \& Molnar (1983)] given a geothermal gradient of around 30 ${ }^{\circ} \mathrm{C} \mathrm{km}^{-1}$ in western Taiwan (Wu et al. 2013). Finally, we include a layer from 15 to $45 \mathrm{~km}$ depth that includes the deepest earthquakes, which accounts for 16 per cent of the total seismicity.

The focal mechanism data set comprises 2465 events with magnitudes ranging from 1.4 to 6.8 , with a mean $M_{\mathrm{L}}$ of 3.6 (Fig. 5a) and where the 90 per cent of the events' magnitudes range between 2.5 and 4.8 (see Supporting Information Table S1). Focal mechanisms were calculated using first motion polarities of $P$-waves (Wu et al. 2008). Each focal mechanism was assigned a quality index factor (Qfp) to assess the uncertainty and solution quality depending on the number of polarity readings (Npor), the azimuthal gap (Gap), a relative number of up versus down polarity readings (Rup) and the data fit from the genetic focal mechanisms' estimation algorithm (for details on Qfp calculations see Wu et al. 2008). Values for Qfp, Npor, Gap and Rup can be found in Supporting Information Table $\mathrm{S} 1$. The data set is composed of focal mechanisms' solutions with Npor $>10$ and Gap $<180^{\circ}$ and, generally, a solution is considered to be unconstrained if Qfp $=0$, and good with Qfp $>1(\mathrm{Wu}$ et al. 2008). All event locations and focal mechanism solutions, which include strike, dip, rake with standard deviations $(1 \sigma)$, and the corresponding $P$-, $T$ - and $B$-axes are also presented in Supporting Information Table $\mathrm{S} 1$.

The data set has been divided into clusters (Fig. 5) where the proximity of events and their distribution in swarms (i.e. main shock and aftershocks) were taken into account. Each cluster has a minimum of 20 events (except cluster A4 with 17 events), which have been shown to be a sufficient number to give a stable inversion result (e.g. Hardebeck \& Hauksson 2001; Townend \& Zoback 2006; Arnold \& Townend 2007; Vavrycuk 2014) and 29 of the clusters have more than 30 events. In keeping with Wu et al. $(2008,2010)$ and Chen et al. (2017), we use only events with a Qfp $>0.1$. Overall, the clusters have an average of Qfp $1.15 \pm 0.46$ (average of the median cluster Qfp), with only an 11 per cent \pm 6 in average of percentage of events with Qfp $<0.2$ in each cluster (Supporting Information Table S2). 19 clusters have a median Qfp $>1$, which we consider being high-quality clusters. 11 clusters have a median Qfp between 0.7 and 1, which is fair, and 6 have median Qfp below 0.7, which is acceptable (Wu et al. 2008; Supporting Information Table S2 contains more information on cluster Qfp statistics). In the stress inversion all events are treated equally, with no weighting being applied.

The focal mechanism data in the various clusters are displayed in Supporting Information Fig. S1. We show nodal plane normals, $P$ - and $T$-axes and the faulting states, and see that most clusters 


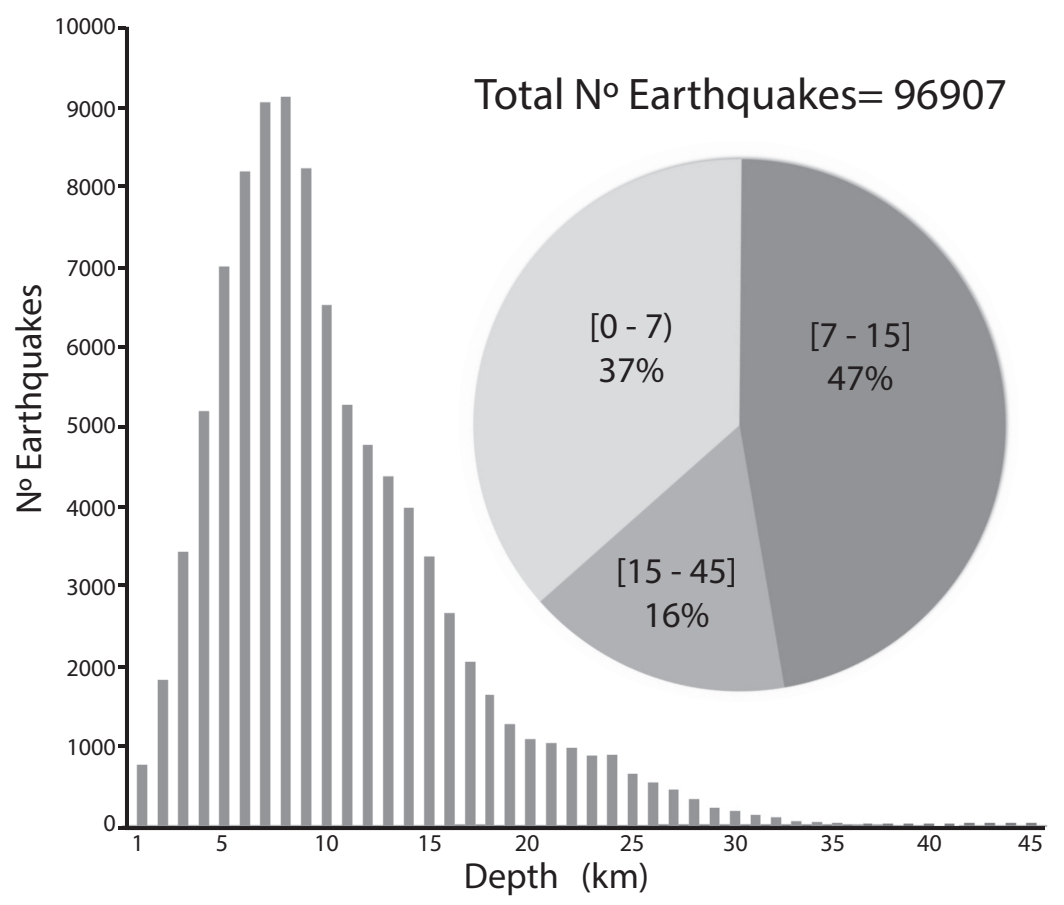

Figure 4. Depth distribution histogram for the seismicity in the study area from 1994 through 2014. The pie plot shows the percentage of seismicity for each depth level discussed in the text.

have rather well-defined directions of $P$-, $T$-axes and nodal plane normals, while some (A7, B11, B17 or C3) show more scattered directions. The distributions of $P$ - and $T$-axes suggest that events in some clusters are produced by a thrust state of stress ( $T$-axes roughly vertical, $90^{\circ}$ away from $P$-axes; B8, B9, B10, B16 and C4), some by a strike-slip environment $\left(90^{\circ}\right.$ along the horizontal between $P$ and $T$-axes; A8, A9, B1 and B5) and a few by a normal state of stress $\left(P\right.$-axes roughly vertical, $90^{\circ}$ away from $T$-axes; A11, A13 and B13). Other clusters seem to be located in more oblique stress states of either transtenstion or transpression, where some $P$ - and $T$-axes show thrust or normal and other strike-slips (A3, A11, A12, B4 and B6; column A of Supporting Information Fig. S1). However, as individual focal mechanisms can vary significantly even when events are produced by the same stress state (e.g. McKenzie 1969), we need a formalized inversion methodology to assess the causative stresses in the clusters.

To estimate the principal stress directions $\left(\sigma_{1}, \sigma_{2}\right.$ and $\left.\sigma_{3}\right)$, we use the stress tensor inversion scheme of Lund \& Slunga (1999). The methodology accounts for uncertainties in the focal mechanisms by perturbations to the $P$-, $T$ - and $B$-axes up to some angle during the inversion (Lund \& Slunga 1999; Hensch et al. 2016). Here we allowed $10^{\circ}-15^{\circ}$ maximum perturbation in keeping with the $18^{\circ}$ average focal mechanism uncertainty estimated by Wu et al. (2008). In order to select which of the two nodal planes is the most likely fault plane, the Lund \& Slunga (1999) methodology applies a Mohr-Coulomb stability criterion to assess which nodal plane is more unstable over a range of coefficient of friction $(\mu)$ values. Here we use a $\mu$-range of $0.4-1.2$ and if one nodal plane is consistently more unstable over this range, that nodal plane is chosen as the fault plane and used in the inversion. If, on the other hand, the most unstable nodal plane changes over this range then the nodal planes are similarly stable and choosing one over the other would mean an implicit choice of $\mu$. The fault plane is then instead chosen based on the goodness of fit. Using the focal mechanisms of the considered cluster, the inversion performs a grid search of the principal stress directions and the stress ratio $R=(\sigma 1-\sigma 2) /(\sigma 1-$ $\sigma 3)$. For each point on the grid it searches through all perturbations of the focal mechanisms and for each calculates the angular misfit between the shear stress direction on the chosen fault plane and the observed slip direction. This process determines the directions of the three principal stress axes and an estimate of the relative size of the intermediate principal stress, the stress ratio $R$ (Lund $\&$ Slunga 1999). When the entire set of focal mechanisms of the cluster has been searched at all stress directions, the optimal stress tensors and its confidence limits are calculated using statistics for one-norm misfit (Fig. 6, column a). The direction of the maximum compressive horizontal stress $\left(S_{\mathrm{H}}\right)$ and its confidence limits are then determined using the methodology of Lund \& Townend (2007). The $S_{\mathrm{H}}$ results are plotted as a histogram around the stereonet (Fig. 6, column a). In map view, $S_{\mathrm{H}}$ is plotted as wedges that represent the 95 per cent confidence interval (Fig. 7) and the stress regime of each (i.e. reverse, normal, strike-slip) is determined from the stress tensor. Then, the poles to the estimated fault planes, determined from the two nodal planes of each focal mechanism (e.g. Lund \& Slunga 1999), are plotted and contoured using the Kamb method (Fig. 6, column b). We also plot the strikes of the estimated fault planes in a rose diagram (Fig. 6, column c) using the Stereonet3D software of Allmendinger et al. (2012). The length of the petals corresponds to the percentage of the total number of strikes that fall within a $10^{\circ}$ bin, and the two most frequent strikes are chosen as the primary (most frequent) and secondary fault planes (Fig. 7). Finally, to assess how the instability fault selection criterion performed we note that on average 70 per cent \pm 12 per cent of the fault planes were chosen based on stability and that in only three clusters (A4, B14 and B16) were less than 50 per cent of the planes chosen by stability (Supporting Information Table S2). In Supporting Information Fig. S1 we illustrate the chosen fault planes in MohrCoulomb diagrams, with the relative stress magnitudes calculated 

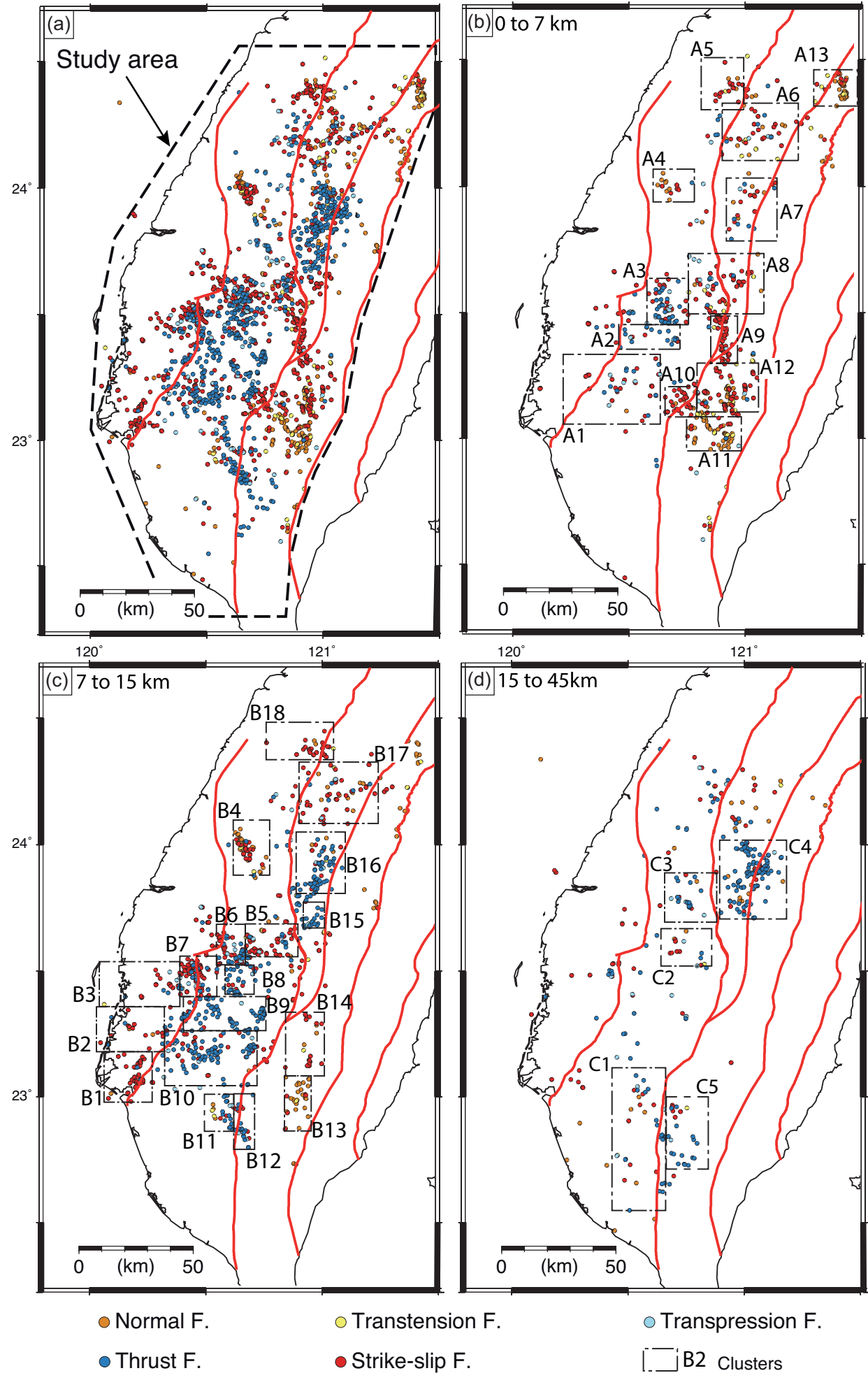

- Thrust F.

- Strike-slip F.

[-]B2 Clusters

Figure 5. (a) Distribution and faulting type for all focal mechanisms used in this study. The location of the study area is shown with a black dashed line. The faulting types follow the classification scheme of Zoback (1992). (b) The 0-7 km depth level with 13 clusters labelled A1 to A13. (c) The 7-15 km depth level with 18 clusters labelled B1 to B18. (d) The 15-45 km depth level with 5 clusters labelled C1 to A5. Clusters correspond to the results shown in Fig. 6 and Supporting Information Fig. S1.

in the inversion using an average coefficient of friction $(\mu)$ of 0.6 (Supporting Information Fig. S1, column G). A complete set of inputs and outputs for each cluster is given in Supporting Information Fig. S1.

\subsection{Stress tensors and maximum horizontal compressive stress}

An analysis of faulting types (calculated using the method of Zoback (1992)) shows that strike-slip and thrust faulting dominate in the 
(a)

A1 $\mathrm{N}=43 \mathrm{R}=0.90 \mathrm{Dev}: 7.9^{\circ}$ Mis: 0.137
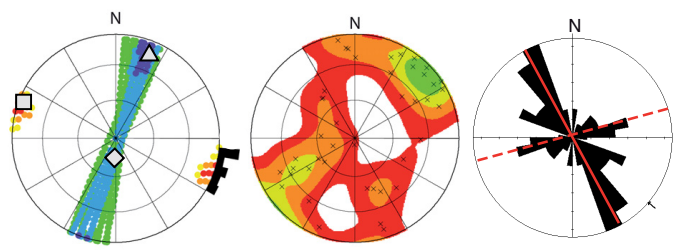

A2
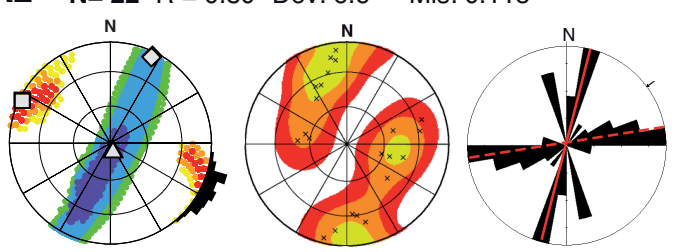

A3 N=78 R=0.90 Dev: $9.7^{\circ}$ Mis: 0.169
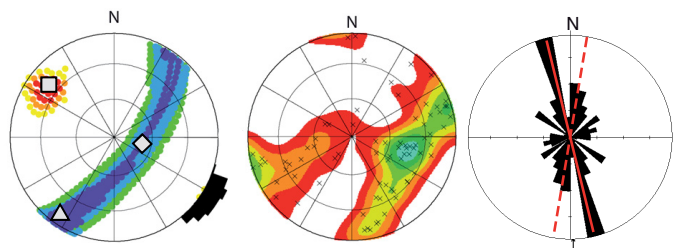

A4 $\mathrm{N}=17 \mathrm{R}=0.70$ Dev.: $5.9^{\circ}$ Mis: 0.104
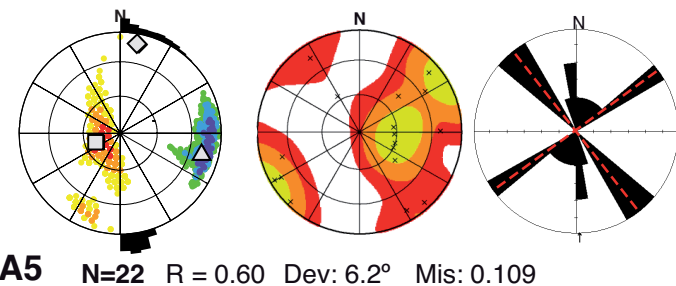

A5 $\mathrm{N}=22 \mathrm{R}=0.60$ Dev: $6.2^{\circ}$ Mis: 0.109
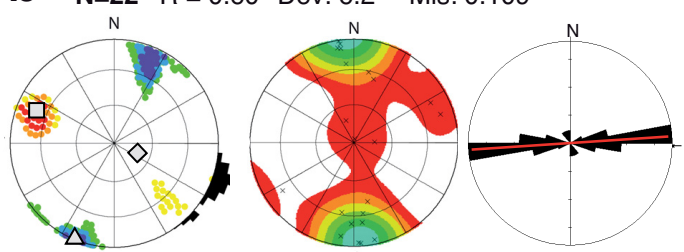

A6 $\mathrm{N}=44 \mathrm{R}=0.80 \mathrm{Dev}: 8.7^{\circ}$ Mis: 0.151
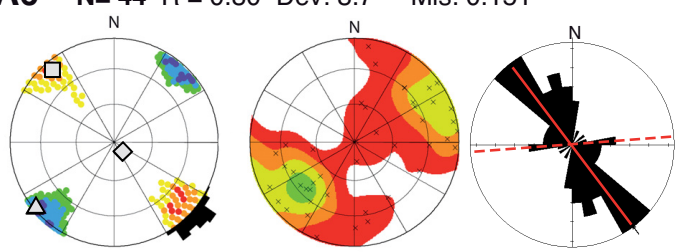

Principal Stresses

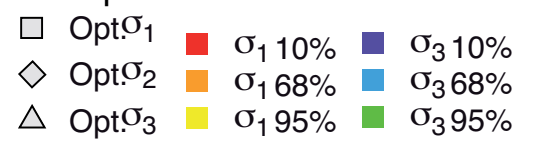

(a)

(b)

(c)
A7 $\mathrm{N}=29 \mathrm{R}=0.90$ Dev.: $15.7^{\circ}$ Mis: 0.274

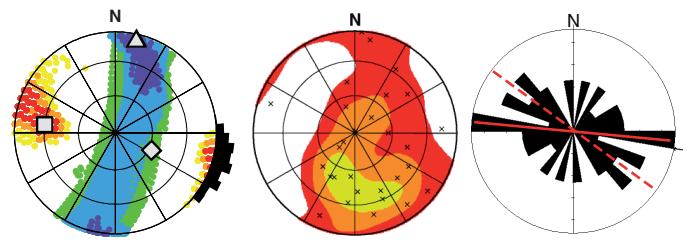

A8 $\mathrm{N}=70 \mathrm{R}=0.70 \mathrm{Dev}: 11.9^{\circ}$ Mis: 0.208
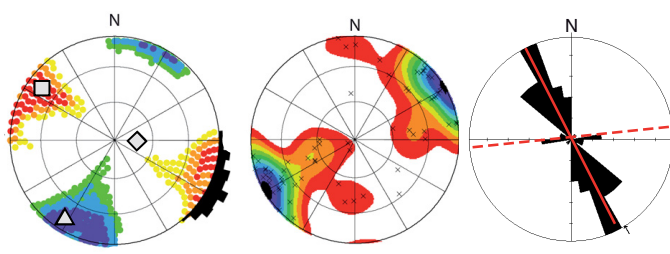

A9 $\mathrm{N}=71 \mathrm{R}=0.50$ Dev: $7.1^{\circ}$ Mis: 0.125

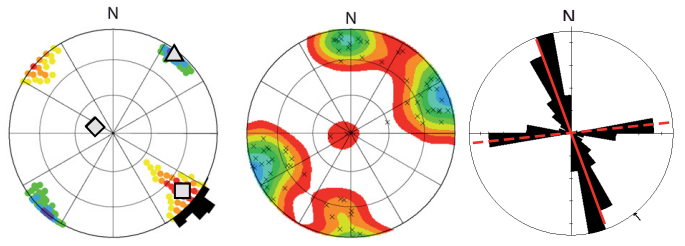

A10 N=43 R $=0.60$ Dev: $5.8^{\circ}$ Mis: 0.100
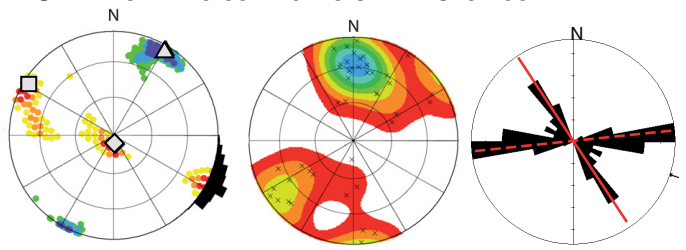

A11 $\mathrm{N}=69 \mathrm{R}=0.50$ Dev.: $10.0^{\circ}$ Mis: 0.174
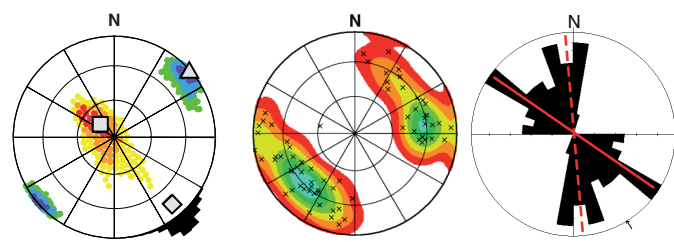

A12 N=140 R = 0.60 Dev: $6.8^{\circ}$ Mis: 0.119
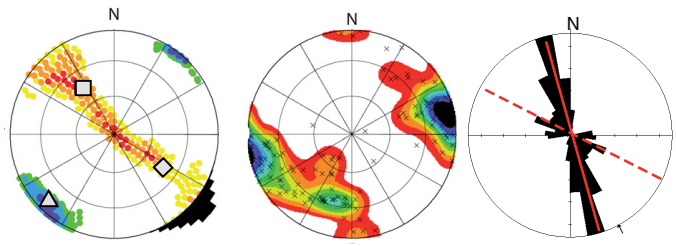

\section{Selected Fault Planes}

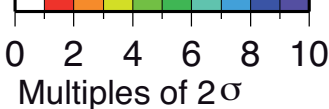

Figure 6. Results from the inversion of earthquake focal mechanisms for each cluster shown in Fig. 5. Column (a) is the best-fitting Principal stress directions on lower hemisphere equal area plots, with confidence regions of $\sigma_{1}$ (red colours) and $\sigma_{3}$ (blue colours), and the optimal solution (symbols). Histograms of $S_{\mathrm{H}}$ direction are shown on the periphery of the stereonet. Column (b) shows the Kamb contours of the poles to the selected fault planes that best fit the stress tensor. Column (c) shows rose diagrams of the strikes of the selected fault planes from column (b), highlighting the mean strike of the primary (solid) and secondary (dashed) fault families in red. N, number of events; R, relative size of the intermediate principal stress; Dev, deviation; Mis = misfit. The location of the clusters are shown in Fig. 5. A complete output from the inversion is given in Supporting Information Fig. S1. 
A13 $\mathrm{N}=70 \mathrm{R}=0.80$ Dev: $8.3^{\circ}$ Mis: 0.145
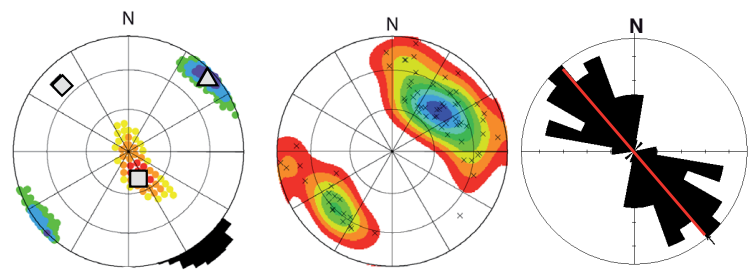

B1 $\mathrm{N}=55 \mathrm{R}=0.80$ Dev.: $6.0^{\circ}$ Mis: 0.104
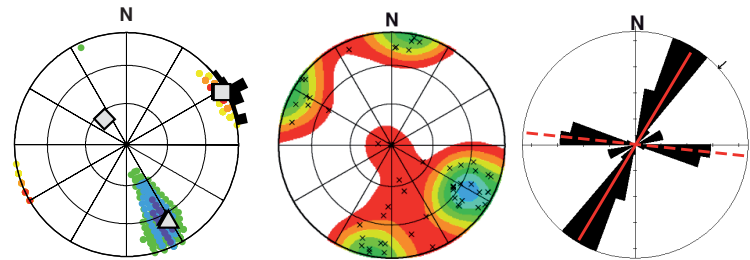

B2 $\mathrm{N}=30 \mathrm{R}=0.80$ Dev: $6.3^{\circ}$ Mis: 0.109
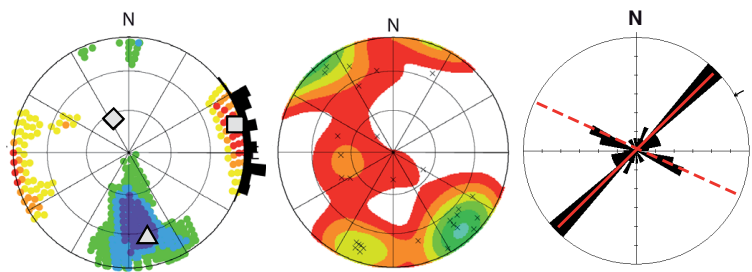

B3 $\mathrm{N}=27 \mathrm{R}=0.90$ Dev: $8.5^{\circ}$ Mis: 0.148
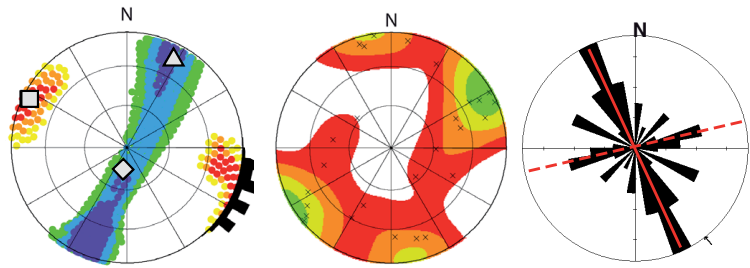

B4 $\mathrm{N}=73 \mathrm{R}=0.60$ Dev: $7.0^{\circ}$ Mis: 0.122
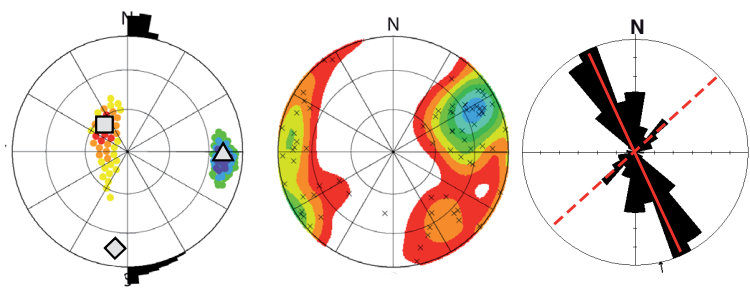

B5 $\mathrm{N}=92 \mathrm{R}=0.70$ Dev: $10.2^{\circ}$ Mis: 0.179
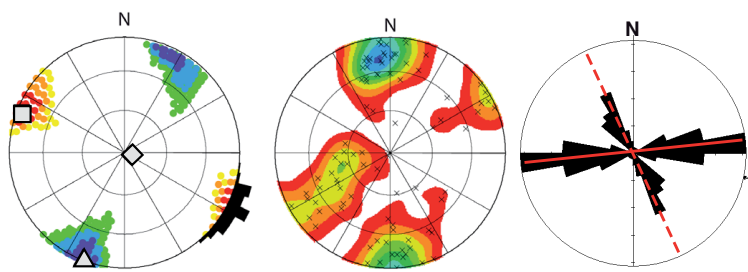

Figure 6. Continued.

fold-and-thrust belt (Fig. 5a). Strike-slip faulting occurs mostly in the Coastal Plain and in the Western Foothills at about $23.5^{\circ} \mathrm{N}$ to a depth of $15 \mathrm{~km}$, whereas thrusting and transpressional faulting dominate in the Western Foothills and the Hsuehshan Range from the surface to the base of the seismicity (Figs 5b-d). Extensional faulting in the northwest (clusters A4 and B4) and strike-slip faulting in the southeast (cluster A9) are related to the Chi-Chi
B6
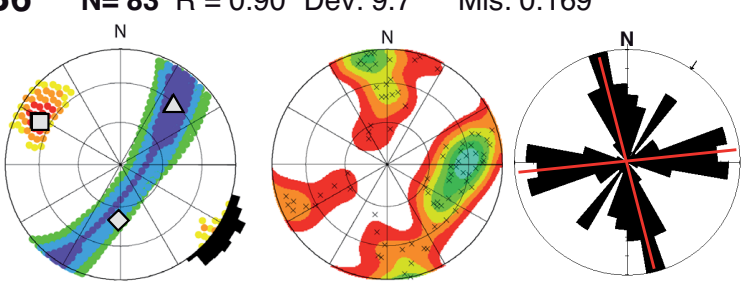

B7 $\mathrm{N}=94 \quad \mathrm{R}=0.90$ Dev: $5.9^{\circ}$ Mis: 0.103
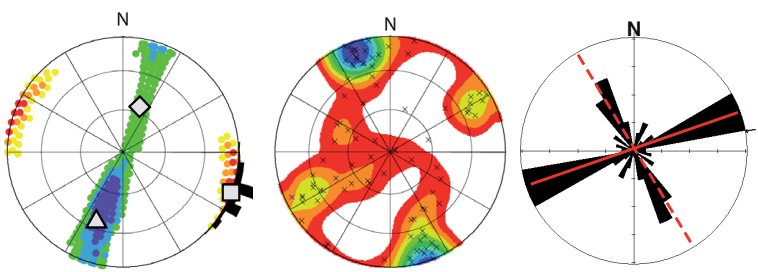

B8 $\mathrm{N}=30 \mathrm{R}=0.70$ Dev: $8.2^{\circ}$ Mis: 0.143
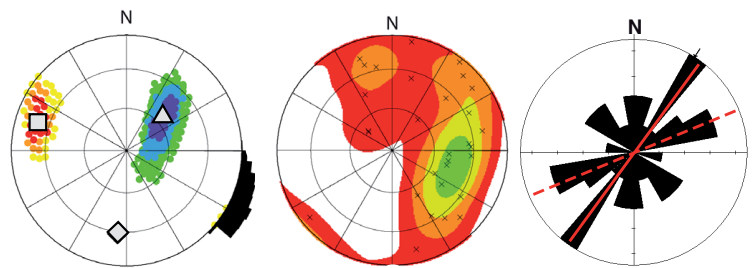

B9 $\mathrm{N}=75 \mathrm{R}=0.80$ Dev: $9.2^{\circ}$ Mis: 0.160
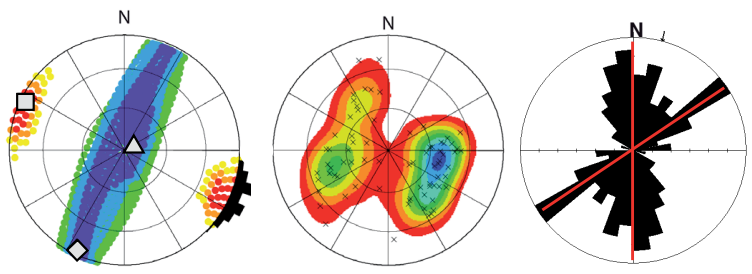

B10 N=136 R = 0.90 Dev: 12.3 Mis: 0.215
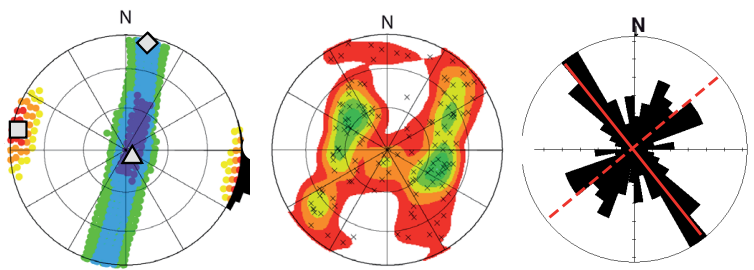

B11 $\mathrm{N}=40 \mathrm{R}=0.90$ Dev: $14.9^{\circ}$ Mis: 0.261

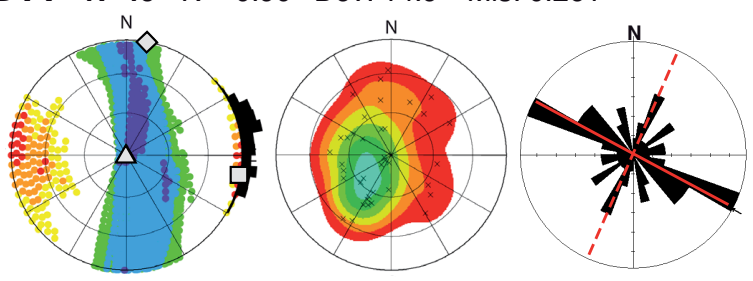

earthquake sequence. Extensional and strike-slip faulting dominate at all depths along the western flank of the Central Range, with thrusting being common at the deepest level in the south (Figs 5b-d).

Throughout the fold-and-thrust belt, $\sigma_{1}$ at all depth levels generally plunges gently towards the west-northwest to west (Fig. 6, column a). There are local exceptions to this, such as clusters B1, 
B12 $\mathrm{N}=40 \mathrm{R}=0.70$ Dev.: $8.6^{\circ}$ Mis: 0.150

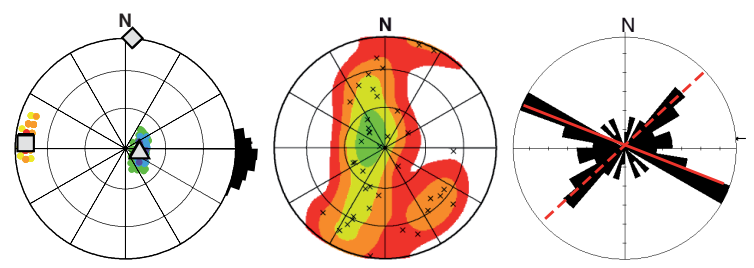

B13 $\mathrm{N}=36 \mathrm{R}=0.60$ Dev.: $5.2^{\circ}$ Mis: 0.091
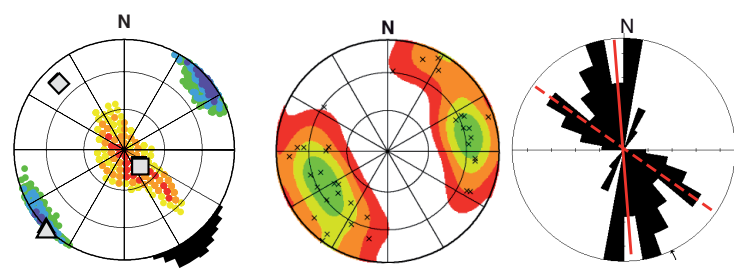

B14 N=25 R =0.70 Dev: $6.3^{\circ}$ Mis: 0.111
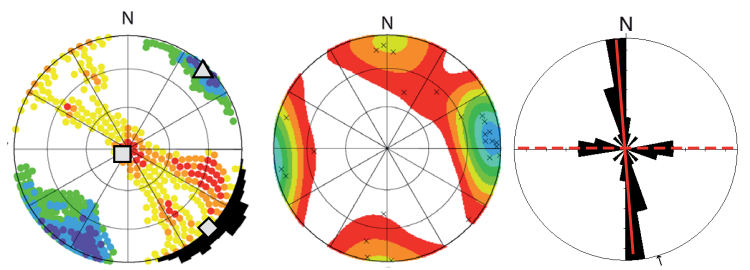

B15 N=27 R=0.80 Dev.: $3.7^{\circ}$ Mis: 0.065
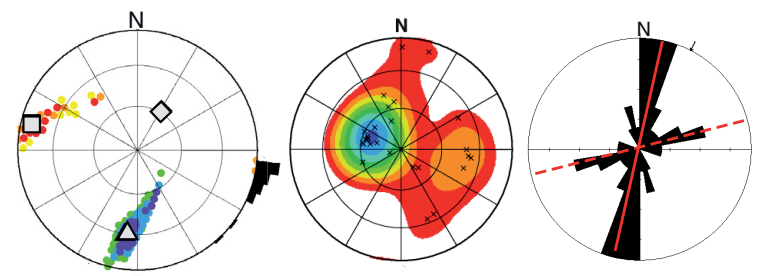

B16 $\mathrm{N}=48 \mathrm{R}=0.60$ Dev: $13.3^{\circ}$ Mis: 0.232
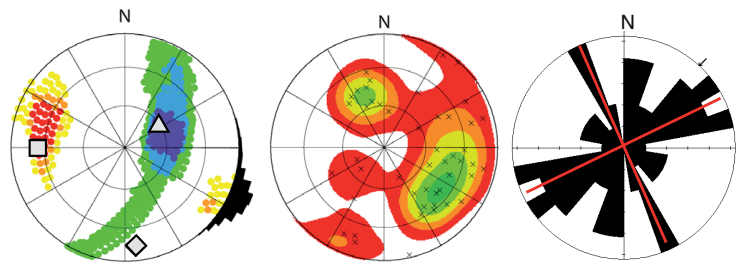

B17 N=61 R=0.60 Dev: $10.3^{\circ}$ Mis: 0.179
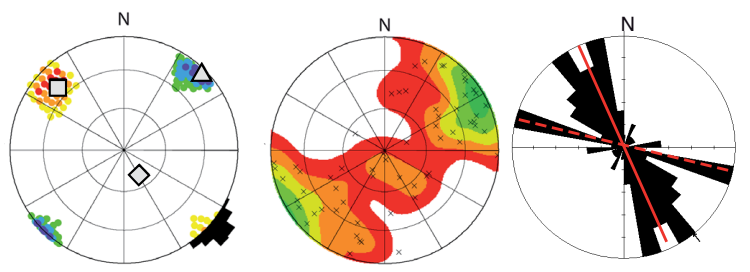

Figure 6. Continued.

$\mathrm{B} 2$ and $\mathrm{C} 1$ in which $\sigma_{1}$ plunges gently east-northeast. From 0 to $7 \mathrm{~km}$ depth, the state of stress in the Coastal Plain, Western Foothills and Hsuehshan Range is predominantly in the strike-slip regime. In the southern part of the Western Foothills, from 7 to $15 \mathrm{~km}$ depth, there is a dominantly compressional stress regime that is important. Although there are few data in the 15-45 km depth level, these show a compressional stress regime in the north and a strike-slip regime in the central and southern parts of the study area. An extensional
B18 $\mathrm{N}=29 \mathrm{R}=0.60$ Dev: $7.0^{\circ}$ Mis: 0.122
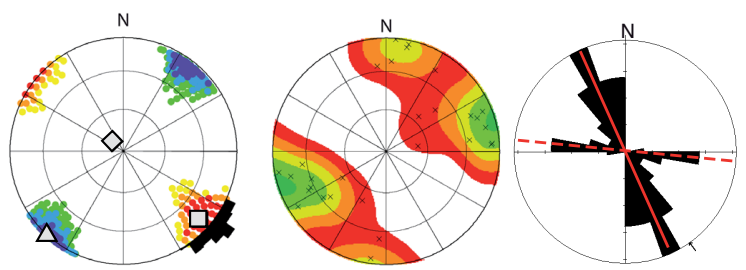

C1 $\mathrm{N}=35 \mathrm{R}=0.90$ Dev: $15.5^{\circ}$ Mis: 0.270
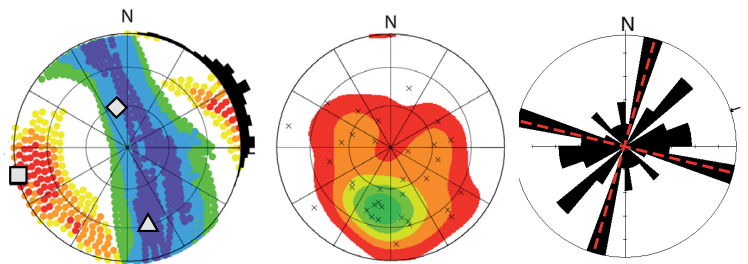

C2 $\mathrm{N}=20 \mathrm{R}=0.70$ Dev: $10.0^{\circ}$ Mis: 0.175
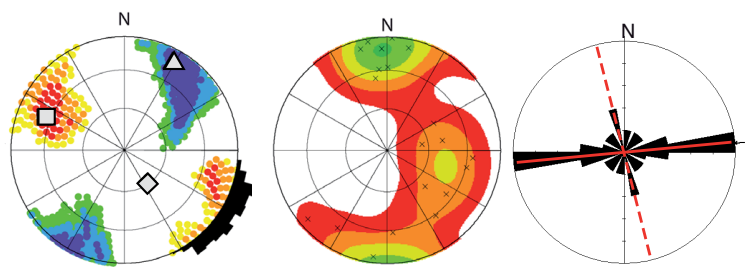

C3 $\mathrm{N}=30 \mathrm{R}=0.80$ Dev.: $8.5^{\circ}$ Mis: 0.148
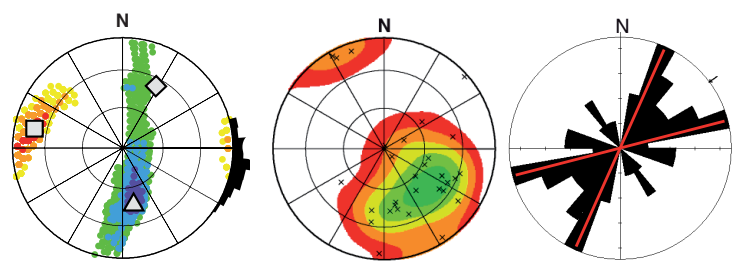

C4 $\mathrm{N}=165 \mathrm{R}=0.70 \mathrm{Dev}: 8.6^{\circ}$ Mis: 0.150
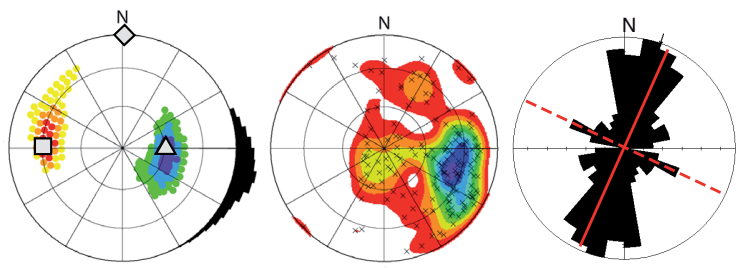

C5 $\mathrm{N}=49 \mathrm{R}=0.80$ Dev: $7.4^{\circ}$ Mis: 0.130

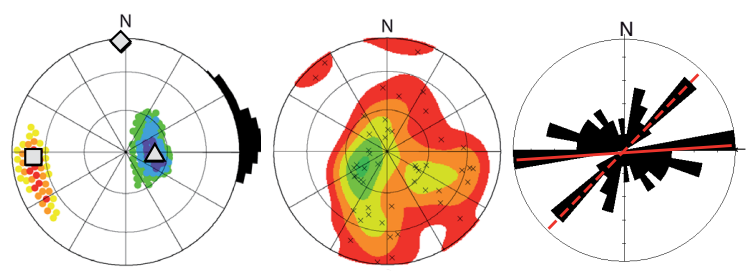

stress regime is rare in the fold-and-thrust belt, being found only in clusters $\mathrm{A} 4$ and $\mathrm{B} 4$, where $\sigma_{3}$ plunges gently towards the eastsoutheast. An extensional stress regime is common, however, in the upper $15 \mathrm{~km}$ of the Central Range, where $\sigma_{3}$ is gently northeast and southwest plunging (clusters A11, A12, A13, B13 and B14). At the deepest level, in the southern part of the Central Range, a compressional stress regime dominates, with $\sigma_{1}$ plunging gently towards the west (cluster C5). 

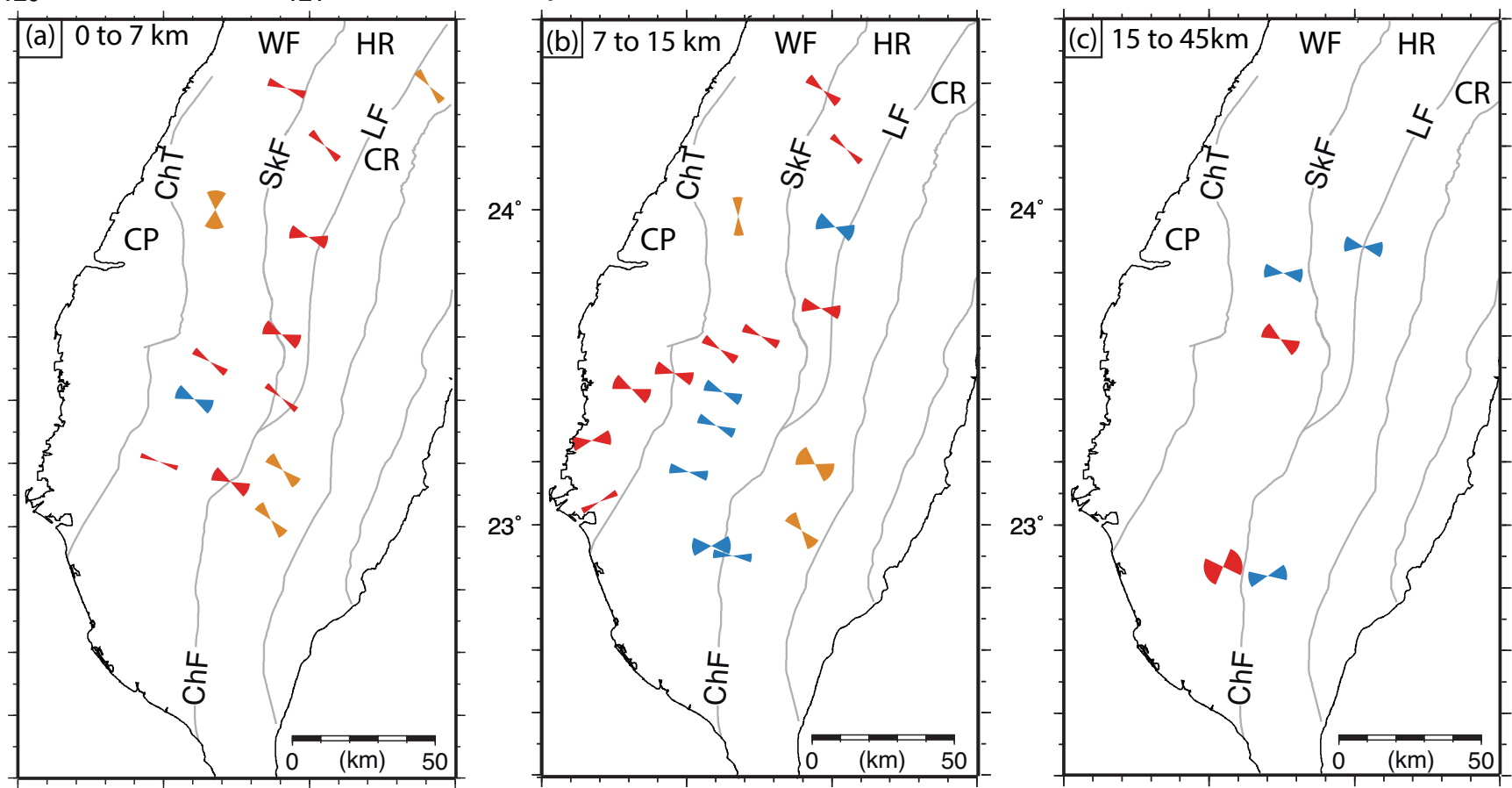

${ }^{-}$Normal Faulting (NF)

Figure 7. The direction of the maximum horizontal compressive stress $\left(S_{\mathrm{H}}\right)$ for each cluster at their respective depth level. Each wedge corresponds to the 95 per cent confidence interval. The result from each cluster is coloured depending on the fault type. (a) The $0-7 \mathrm{~km}$ depth level, (b) the 7-15 km depth level and (c) the 15 to $45 \mathrm{~km}$ depth level. All the relevant data of the resultant inversion for each cluster are in Fig. 6 and the location of the clusters in Fig. 5. Labels of faults and tectono-stratigraphic units are as in the inset of Fig. 1.

Throughout the fold-and-thrust belt, the direction of the maximum compressive horizontal stress $\left(S_{\mathrm{H}}\right)$ varies appreciably from north to south, although it shows only minor, local variation with depth (Fig. 7). In general, the direction of $S_{\mathrm{H}}$ fans from roughly northwest in the north (clusters A4 and B4 are exceptions), through to west-southwest in the southwest part of the study area. The direction of $S_{\mathrm{H}}$ in the Central Range is constantly northwest oriented, except at the deepest depth level in the south, where it is westsouthwest oriented.

\subsection{Most likely active fault planes}

A derivative of the process of determining the stress tensor is the possibility to estimate the most likely fault plane orientations and kinematics for the region of each earthquake cluster (Fig. 8). We have done this using the fault selection during inversion methodology outlined above and orientations are given following the righthand rule. The quality of the fault plane determinations can be observed from the deviation angles (Dev in Fig. 6; defined as the mean of the angular differences in the fault planes between the observed slip directions and the directions of calculated maximum shear stress) given for each cluster. As an estimate of quality, we divide the results into three classes based on the estimated average uncertainties in the focal mechanisms (Wu et al. 2008): $<10^{\circ}$ is good ( 26 clusters), $10^{\circ}$ to $15^{\circ}$ is fair ( 8 clusters), and $>15^{\circ}$ is poor ( 2 clusters; Lund \& Slunga 1999). From 0 to 7 km depth (Fig. 8a), northwest to north-northeast striking sinistral transpressional faulting to thrust faulting dominate in the southern part of the Western
Foothills, whereas nearly east striking dextral strike-slip faulting and northwest striking dextral transtensional faulting occur in the north. Roughly northwest striking sinistral transpressional faulting dominates in the Hsuehshan Range, whereas northwest striking extensional to sinistral transtensional faultings are typical in the Central Range. From 7 to 15 km depth (Fig. 8b), north-northwest and north-northeast striking dextral and sinistral strike-slip faultings are common in the south of the Coastal Plain. Faulting in the southern part of the Western Foothills is characterized by north-northwest and north-northeast striking dextral and sinistral transpressional faultings together with north-northeast and north striking thrust faultings, whereas in the north only northwest striking transtensional faulting takes place. The central part of the Western Foothills is dominated by a zone of east-northeast striking, dextral strikeslip faulting (Fig. 8b). At this depth level, the Hsuehshan Range is characterized by northwest through northeast striking sinistral and dextral transpressional and thrust faulting. The southern part of the Central Range has roughly north striking extensional faulting with predominantly roughly east-west sinistral transpressional faulting in the immediate hanging wall of the Chaochou fault. From 15 to $45 \mathrm{~km}$ depth (Fig. 8c), southwest and nearly east striking dextral transpressional faulting is taking place in the Western Foothills, whereas in the far southeast north striking dextral faulting is taking place in the immediate footwall to the Chaochou fault. At this depth level, in the Central Range north-northeast striking thrust faulting is taking place along the hanging wall of the Lishan fault, and roughly east-west sinistral strike-slip faulting in the immediate hanging wall of the Chaochou fault. 


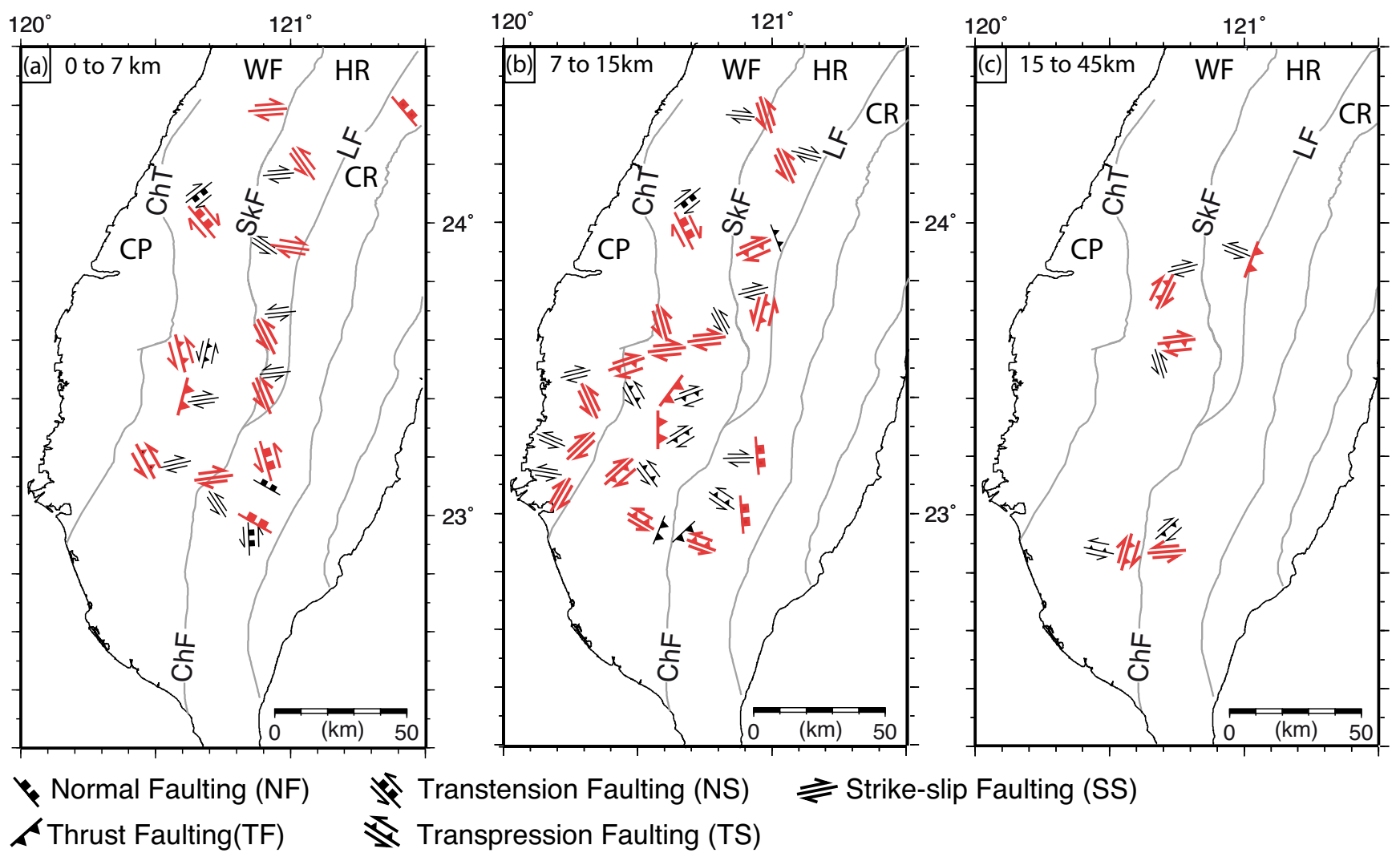

Figure 8. Selected fault planes' orientations with their interpreted kinematics depending on $\sigma_{1}, \sigma_{2}$ and $\sigma_{3}$ and $S_{\mathrm{H}}$ from the inversion results shown in Figs 6(b) and (c) (primary orientations/kinematics in red, secondary in black). (a) The 0-7 km depth level, (b) the 7-15 km depth level and (c) the 15-45 km depth level. All the relevant data of the resultant inversion for each cluster are in Fig. 6 and the location of the clusters in Fig. 5. Labels of main faults and tectono-stratigraphic units are as in the inset of Fig. 1.

\section{DISPLACEMENT AND STRAIN RATE ANALYSIS FROM GPS DATA}

\subsection{Data and methodology}

In this section we investigate the deformation and strain rates of the south-central Taiwan fold-and-thrust belt and the western flank of the Central Range using data from the Taiwan GPS network. The station coverage of the network is dense in most of the study area (Fig. 9a), with the exception of the high mountainous areas of the Central Range, the east-central part of the Western Foothills and the southern part of the Hsuehshan Range. The data set used here is from the period 2005 through 2009 and was processed according to the method of Yu et al. (1997), and the reader is referred there for details. Horizontal velocities are calculated relative to station S01R located on the island of Penghu, in the Taiwan Strait on stable Eurasia. Strain rates are calculated from the GPS data using the SSPX software of Cardozo \& Allmendinger (2009), and the reader is referred there for the background theory. We used a $5 \mathrm{~km} \times$ $5 \mathrm{~km}$ grid and a grid-nearest neighbour interpolation method using the 10 nearest stations within a maximum radius of $35 \mathrm{~km}$. SSPX determines the best-fitting strain tensors for each 2-D surface of the grid and its corresponding strain ellipse. In Fig. 9, we show the displacement vectors, the rotation rate about a vertical axis, the dilatation strain rate and the maximum shear strain rate, as well as the horizontal maximum compressive $\left(\varepsilon_{\mathrm{H}}\right)$ and extension strain axes and the maximum shear strain planes. For the sake of clarity in Fig. 9, only every second set of horizontal maximum compressive and extension axes is plotted. Below we describe the data set using the kinematic analysis of a body of rock that undergoes translation, rotation, dilation and shear.

\subsection{Displacement vectors and strain rates of south-central Taiwan}

The horizontal velocity vectors display an overall northwest to westnorthwest sense of displacement in the northern part of the study area, changing to dominantly west directed in the central and much of the southern areas (Fig. 9a). In the southwest, along the coast, the velocity vectors are more southwest directed. Horizontal displacement along the northwestern part of the Western Foothills and throughout the Coastal Plain is very small, whereas in the rest of the study area the horizontal velocities increase overall towards the south and east.

The sense of vertical rotation undergoes several changes from north to south (Fig. 9b), with a clockwise rotation dominating in the Hsuehshan Range and the northern part of the Central Range, whereas counter-clockwise rotation is more common in the northern part of the Western Foothills and the Coastal Plain. From about $23.5^{\circ} \mathrm{N}$ to $22.8^{\circ} \mathrm{N}$ there is a pronounced zone of clockwise rotation that ends abruptly southward, where a counter-clockwise rotation dominates in the extreme southwest. The dilatation strain rate pattern shows a clear change from west to east across the ChaochouLishan fault system, with negative values (compression) everywhere in the fold-and-thrust belt and positive values (extension) in the Central Range (Fig. 9c). Note, however, that the small number of stations in the Central Range means that there is a large uncertainty 

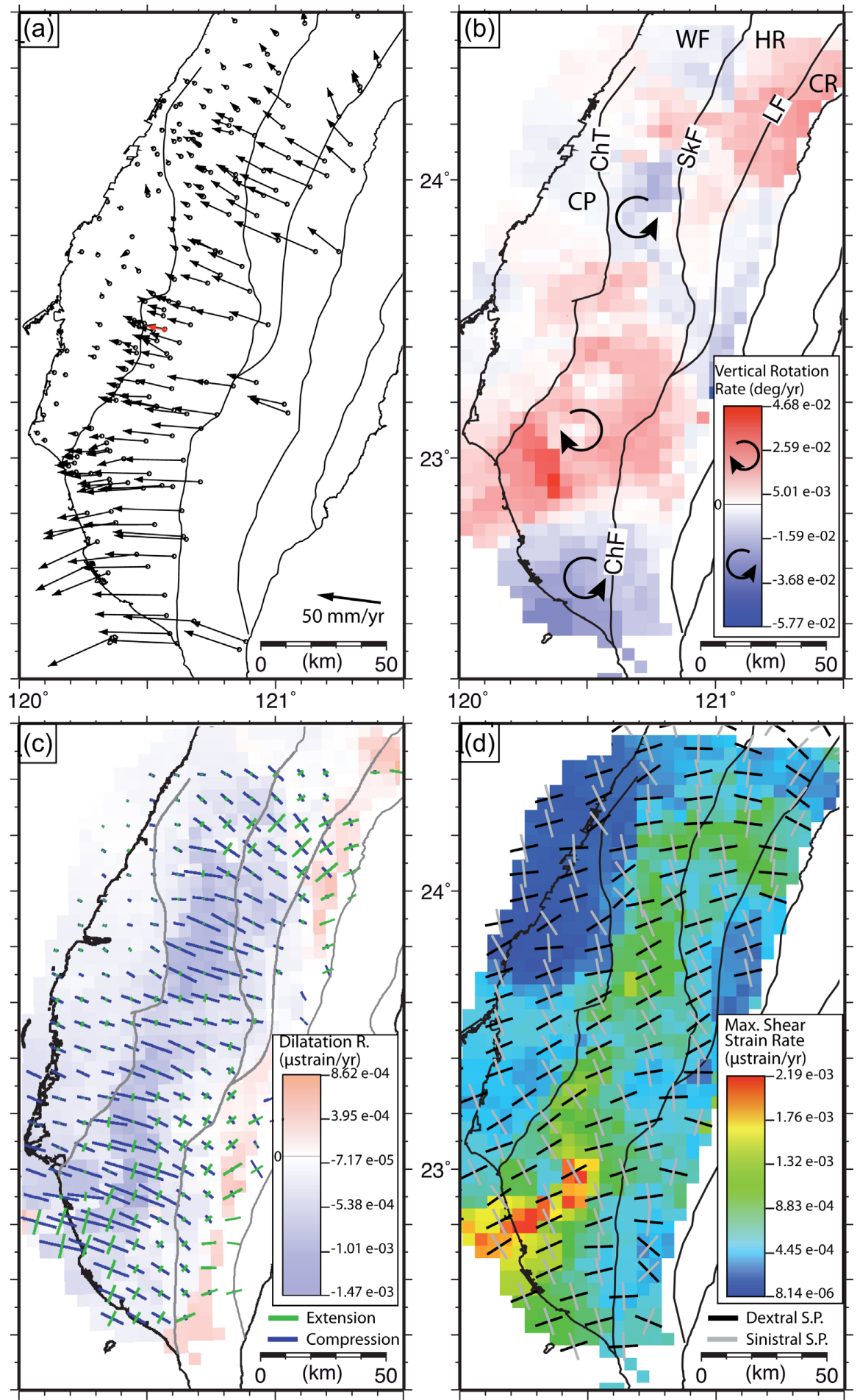

Figure 9. Geodetic velocities and strain rates. (a) GPS horizontal velocity vectors. (b) Vertical rotation strain rate. Blue colours represent counter-clockwise and red colours represent clockwise rotation. (c) Dilatation strain rates. Blue colours representing compression and red extension. The horizontal maximum compression $\left(\varepsilon_{\mathrm{H}}\right)$ and extension strain rate axes are shown by the blue and green lines, respectively. (d) Maximum shear strain rates. Dextral and sinistral shear planes (black and grey lines, respectively) are given. Labels of main faults, tectono-stratigraphic units are shown in (b) and are as in the inset of Fig. 1.

associated with this area. There is a marked decrease in the dilation strain rate in the northwestern part of the Western Foothills and the northern part of the Coastal Plain. The direction of $\varepsilon_{H}$ is oriented roughly northwestwards in the northern and northeastern part of the fold-and-thrust belt, rotating to west-northwest in the central and southern parts (Fig. 9c). In the Central Range, the orientation of the extension axes is roughly northeast in the northern part, becoming more westward to west-southwest in the south. The maximum shear strain rate is fairly uniform throughout much of the study area (Fig. 9d). The Western Foothills show slightly higher shear strain rate than the surrounding areas, and there is a slight southward increase. There is a local, east-northeast striking zone of high shear 
strain rate in the southwest of the study area. There is a marked, although moderate, decrease in the maximum shear strain rate in the northwestern part of the Western Foothills and the northern part of the Coastal Plain and a moderate, roughly east-northeast striking southward increase at about $23.5^{\circ} \mathrm{N}$. The orientations of the dextral maximum shear planes (black in Fig. 9d) change from nearly east-west striking in the northern part of the study area to more southwest striking from $c .24^{\circ} \mathrm{N}$ southward. In the south, the orientations of the dextral maximum shear planes change eastwards from southwest striking to more west striking.

\section{DISCUSSION}

The importance of reactivation of pre-existing faults in the deformation of an area is thought to be such that this process can control the stress distribution in the crust (Célérier, 1995, 2008; Tavani et al. 2015). In the case of pre-existing faults, why reactivation happens is a complex and selective process that depends on several factors, the most important of which are: the orientation and steepness of the pre-existing faults with respect to the principal stress axes, the friction along the fault plane and the geothermal gradient (Sibson, 1985, 1990, 1994; Letouzey 1990; Kelly et al. 1999; Leclère \& Fabbri 2013). Fold-and-thrust belts commonly develop in areas where the basement rocks have undergone a previous deformation history and the sediments that overlie them can also have fault systems, facies changes and possibly a weak contact with the basement (e.g. Rodgers 1990). All of these form heterogeneities that can be (re)activated in the compressional stress field of a developing thrust system (Jackson 1980; Wiltschko \& Eastman 1983; Sibson 1985; Richard \& Krantz 1991; Célérier, 1995, 2008; Turner \& Williams 2004; Butler et al. 2006; Poblet \& Lisle 2011; Bonini et al. 2012; Lacombe \& Bellahsen 2016). Below, we first compare and contrast our results with previous stress and strain studies in the area and then go on to investigate whether or not the reactivation of faults inherited from the Eurasian continental margin is a contributing factor to the contemporaneous stress and strain fields of the south-central Taiwan fold-and-thrust belt.

The result of the contemporaneous stress analysis of the southcentral Taiwan fold-and-thrust belt obtained in this study, which includes the data related to large earthquakes such as Chi-Chi, is in good agreement with that obtained from both palaeostress and contemporaneous stress studies carried out in the same area (e.g. Angelier et al. 1986; Suppe 1995; Lacombe et al. 1999; Chang et al. 2003; Mouthereau \& Lacombe 2006; Wu et al. 2008; Hsu et al. 2009; Chen et al. 2017). For example, our analyses of the direction of the contemporaneous $S_{\mathrm{H}}$ (Fig. 10) show that it undergoes an important east-west change across the Chaochou fault (but not the Lishan fault) and a north-south change that takes place at about $23.5^{\circ} \mathrm{N}$, in agreement with that determined by Chang et al. (2003), Mouthereau \& Lacombe (2006), Wu et al. (2008; 2010), Hsu et al. (2009) and Chen et al. (2017). Likewise, there is a coincidence in that there is a change in the plunge of $\sigma_{1}$, from near vertical in the Central Range to subhorizontal in the Western Foothills and the Hsuehshan Range. Our results also coincide with those of Chen et al. (2017) in that the direction of $S_{\mathrm{H}}$ and the plunge of $\sigma_{1}$ display only minor, if any, change with depth. However, Wu et al. (2010) indicate that there is a $10^{\circ}-20^{\circ}$ counter-clockwise rotation with depth in southern Taiwan that we do not see in our results. Furthermore, palaeostress studies carried out by Angelier et al. (1986), Lacombe et al. (1999) and Chang et al. (2003) are also in general agreement with our calculations of contemporaneous $\sigma_{1}$. All regional GPS studies indicate a change in the horizontal displacement vector in the fold-and-thrust belt from roughly west-northwest in the north to west and southwest in south. This change takes place at about $23.5^{\circ} \mathrm{N}$. Our strain rate results are also in excellent agreement with previous studies carried out in the study area using GPS data (e.g. Bos et al. 2003; Chang et al. 2003; Ching et al. 2007, 2011; Hu et al. 2007; Chen et al. 2017). The close agreement between all studies of the contemporaneous stress and strain fields in the foldand-thrust belt of south-central Taiwan indicates that the features they delineate are robust on a regional scale and can therefore be used to address the hypothesis put forth in Section 1.

The maximum horizontal stress $\left(S_{\mathrm{H}}\right)$ of an area is typically oriented subparallel to the relative plate motion (Zoback et al. 1989; Zoback 1992; Gölke \& Coblentz 1996; Townend et al. 2012), which, in the case of Taiwan, is roughly towards about $306^{\circ}$ (Figs 1 and 10; Yu et al. 1997; Wu et al. 2016). Large intraplate forces, such as isostatic compensation or lithosphere flexure, can also have an important effect on the regional stress field, while at a more local scale $S_{\mathrm{H}}$ can also be affected by features such as weak faults, structural highs, recent sedimentation or topography (e.g. Tingay et al. 2005). In the study area, there is a marked contrast in the direction of $S_{H}$ from north to south (Fig. 10). In the north, the direction of $S_{\mathrm{H}}$ remains roughly subparallel to the relative plate motion vector from the Central Range westwards into the Coastal Plain. In the south, however, there is a nearly $45^{\circ}$ counter-clockwise rotation in the direction of $\mathrm{S}_{\mathrm{H}}$ from the Central Range westwards across the Chaochou fault and into the Coastal Plain [Fig. 10; see also Chang et al. (2003), Wu et al. (2010), Chen et al. (2017)]. The direction of $\varepsilon_{\mathrm{H}}$ and the orientations of the dextral maximum shear planes both display an overall rotation southwards ( Figs 9 and 10c).

The north-south change in the directions of the contemporaneous $S_{\mathrm{H}}, \varepsilon_{\mathrm{H}}$, the dextral maximum shear planes and the horizontal velocity vectors at about $23.5^{\circ} \mathrm{N}$ has been interpreted to be related to the so-called Peikang High (Fig. 1; Hu et al. 1997; Bos et al. 2003; Chang et al. 2003; Mouthereau \& Lacombe 2006; Ching et al. 2007, 2011; Wu et al. 2008, 2010; Hsu et al. 2009; Chen et al. 2017). Many of these authors interpret the Peikang High to be a symmetrical structural high, or horst (see Twiss \& Moores 1992 for a definition of horst), in the extensional fault system developed on the margin shelf that acts as a symmetrical indenter around which rocks in the fold-and-thrust belt are moving. Nevertheless, as was pointed out by Mouthereau \& Lacombe (2006), neither the palaeostress nor the contemporaneous $\sigma_{1}$ trajectories around the Peikang High fit with those estimated by analogue (Lin \& Huang 1998) and numerical models of it (e.g. J. Hu \& Angelier 1996; Hu et al. 1997; Lin $\&$ Huang 1998). Nor do the contemporaneous stress trajectories, the horizontal displacement field, or the strain field (Fig. 10) fit with those predicted to occur around an indenteLetouzey J.r into a fold-and-thrust belt (e.g. Macedo \& Marshak 1999; Marshak 2004).

Reflection seismic and wide-angle velocity profiling show that from about $23.5^{\circ} \mathrm{N}$ (the southern flank of the Peikang High; Figs 1 and 2) the basement thins from c. $30 \mathrm{~km}$ on the shelf area to less than $10 \mathrm{~km}$ in the area of the failed rift at the base of the slope (e.g. Yeh et al. 2012; Lester et al. 2014; McIntosh et al. 2014; Brown et al. 2017). This is the structural feature that we call the necking zone. Southwards is the morphological feature that is the continental slope. It is across this highly structured area, with its east-northeast strike for both the onset of the necking zone and the shelf/slope break (Figs 1 and 2), its thinning basement and thickening sedimentary cover, and its extensional fault system where the major changes in the stress, strain and displacement fields of the southern part of the Taiwan fold-and-thrust belt take place (Figs 7, 9 


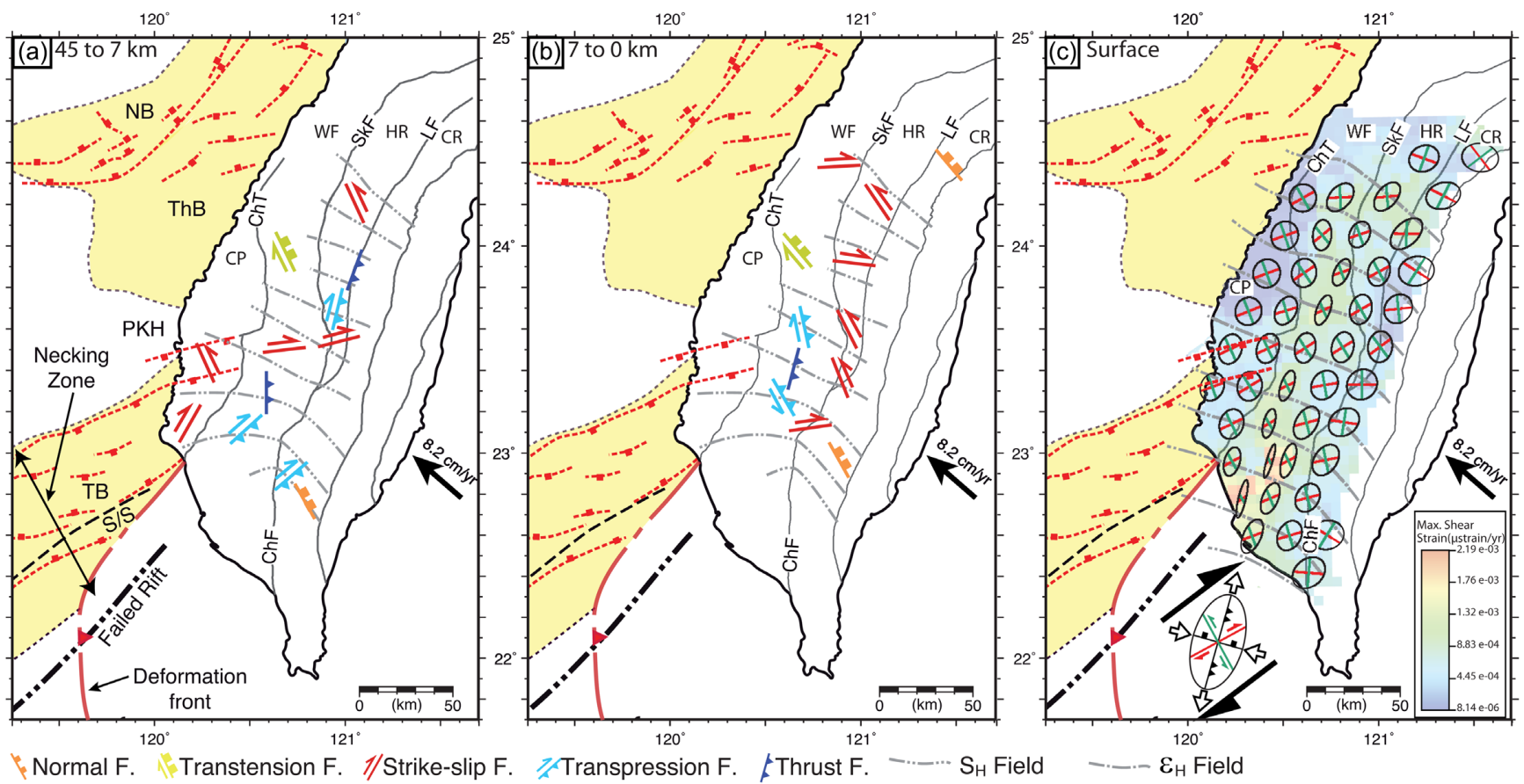

Figure 10. Summary of the stress and strain results for the study area set within the structural and morphological features of the Eurasian continental margin. The relative plate motion vector between the Philippine Sea Plate and Eurasia is shown. (a) The most probable fault planes and their kinematics calculated for the basement (the orientations of the secondary planes are shown in Fig. 8). Interpolated $S_{\mathrm{H}}$ trajectories are shown by dashed grey lines. (b) The most probable fault planes and their kinematics calculated in the fold-and-thrust belt and sedimentary carapace (the orientations of the secondary planes are shown in Fig. 8). $S_{\mathrm{H}}$ as in (a). (c) Maximum shear strain with deformation ellipses determined for groups of four grid units. Dextral and sinistral maximum shear planes are shown in red and green. The interpolated horizontal maximum compression strain rate $\left.\varepsilon_{\mathrm{H}}\right)$ trajectories are shown by the dashed grey lines. The inset shows the expected fault orientations and kinematics in a dextral strike-slip fault system. Labels of faults and tectono-stratigraphic units are as in the inset of Fig. 1. The failed rift axis shown in Fig. 1 is shown by thick black dashed line. S/S, shelf/slope break; TB, Tainan Basin; ThB, Tahishi Basin; NB, Nanjihtao Basin; PKH, Peikang High.

and 10). We therefore suggest, in agreement with Mouthereau \& Lacombe (2006), that the southward change in the $S_{\mathrm{H}}$ direction, in the strain rate derived directions of $\varepsilon_{\mathrm{H}}$ and dextral maximum shear planes, and in the horizontal displacement field vectors that begin at about $23.5^{\circ} \mathrm{N}$ is not due to a symmetrical indenter, but rather to the reactivation of faults related to the complex rifted margin geometry in this area.

The change across the Chaochou fault, but not the Lishan fault, is more difficult to interpret. It is possible that it reflects a local stress perturbation related to differences in the topography from east to west (large difference across the Chaochou fault, but almost no difference across the Lishan fault). It can also, in part, be the effect of differently oriented pre-existing faults in the basement between southern Taiwan and the Hsuehshan Range in the north. Nevertheless, there is close agreement between the inferred extensional faulting stress regime and the strain rate derived extension in the Central Range.

\section{CONCLUSIONS}

In this study, we have shown that there are important changes, particularly in the contemporaneous stress and GPS velocity fields, but also in the strain field, from the continental shelf to the margins' necking zone. In the north of the study area, and along the entire western flank of the Central Range, the $S_{\mathrm{H}}$ and the $\varepsilon_{\mathrm{H}}$ directions are subparallel to the direction of relative plate motion $\left(306^{\circ}\right)$ between the Philippine Sea and the Eurasian plates. In the southwest, where the necking zone of the margin is entering into the deformation of the fold-and-thrust belt, $S_{\mathrm{H}}$, and both the directions of $\varepsilon_{\mathrm{H}}$ and dextral maximum shear planes undergo important rotations. In the case of $S_{\mathrm{H}}$, these rotations go up to $45^{\circ}$. Furthermore, where the upper part of the necking zone is involved in the deformation, the estimated most likely activated fault planes orientation determined from the stress inversion is east-northeast, which is roughly parallel to known fault systems orientation in the basement. The fault type is dominantly dextral strike-slip and transpressive. In the far southwest, an east-northeast striking zone of high shear strain rate coincides with the onshore projection of a failed rift imaged by reflection seismic data offshore. A paucity of seismicity in this area precludes an estimation of the principal stress axes' orientations and determination of fault type, but the calculated strain ellipse is in keeping with it also being a zone of dextral strike-slip faulting (Fig. 10c).

These observations further corroborate our previous interpretations (Brown et al. 2012, 2017; Alvarez-Marron et al. 2014; Camanni et al. 2014, 2016; Biete et al. 2018) that there is a causal link between the reactivation of the inherited morphology and structure of the Eurasian continental margin. In particular, the east-northeast striking fault systems inherited from the necking zone of the continental margin are optimally oriented relative to $S_{\mathrm{H}}$ for reactivation (Sibson, 1990, 1994; Kelly et al. 1999; Leclère \& Fabbri 2013). In the southwest of the study area, therefore, it appears that it is the reactivation of these inherited structures that is controlling the contemporaneous stress field (e.g. Célérier 2008; Tavani et al. 2015) since this stress field is calculated from earthquakes that occur along them. Farther north, however, the close coincidence between 
the directions of $S_{\mathrm{H}}$ and $\varepsilon_{\mathrm{H}}$ with the relative plate motion vector suggest that it is the plate boundary forces that control the stress and strain fields (e.g. Richardson 1992; Zoback 1992; Gölke \& Coblentz 1996).

Finally, there are important north to south changes in both the stress and strain fields from the western flank of the Central Range across the Chaochou-Lishan fault system into the fold-and-thrust belt. The results of both, the stress inversion and the GPS derived strain rates show that the upper crust of western flank of the Central Range (we do not investigate the east part in this study) is under extension while that of the fold-and-thrust belt to the west is under compression. A few data exist in the Central Range for depths greater than $15 \mathrm{~km}$, but these appear to indicate that the deeper crust is under compression (see also, Chen et al. 2017). Nevertheless, there is a clear rotation of the directions of $S_{\mathrm{H}}$ and the directions of $\varepsilon_{\mathrm{H}}$ and dextral maximum shear planes across the Chaochou fault in the south, but no notable change across the Lishan fault in the north. A possible explanation for this difference may be that the north-south differences in topography across this fault system are locally influencing the stress and strain fields (e.g. Richardson 1992; Gölke \& Coblentz 1996).

\section{ACKNOWLEDGEMENTS}

DB, JA-M and CB acknowledge funding provided by the Spanish Ministerio de Ciencia, Innovación y Universidades (former Ministerio de Economia y Competitividad) grants CGL2013-43877-P. H. and PGC2018-094227-B-I00, with additional support from the Generalitat de Catalunya grant 2017SGR1022. The editor A. Ferreira and the reviewers O. Lacombe and V. Vavrycuk are acknowledged. The authors gratefully acknowledge Wessel \& Smith (1998) for the Generic Mapping Tool (GMT) software that was used in plotting some of the figures.

\section{REFERENCES}

Allmendinger, R.W., Cardozo, N. \& Fisher, D.M., 2012. Structural Geology Algorithms Vectors and Tensors, 1st edn, Cambridge Univ. Press.

Alvarez-Marron, J., Brown, D., Camanni, G., Wu, Y.-M. \& Kuo-Chen, H., 2014. Structural complexities in a foreland thrust belt inherited from the shelf-slope transition: insights from the Alishan area of Taiwan, Tectonics, 33, 1322-1339.

Angelier, J., Barrier, E. \& Chu, H.T., 1986. Plate collision and paleostress trajectories in a fold-thrust belt: the foothills of Taiwan, Tectonophysics, 125, 161-178.

Arnold, R. \& Townend, J., 2007. A Bayesian approach to estimating tectonic stress from seismological data, Geophys. J. Int., 170, 1336-1356.

Becker, A., 2000. The Jura Mountains - an active foreland fold-and-thrust belt?, Tectonophysics, 321, 381-406.

Biete, C., Alvarez-Marron, J., Brown, D. \& Kuo-Chen, H., 2018. The structure of southwest Taiwan: the development of a fold-and-thrust belt on a margins outer shelf and slope, Tectonics, 37, 1973-1993.

Bonini, M., Sani, F. \& Antonielli, B., 2012. Basin inversion and contractional reactivation of inherited normal faults: a review based on previous and new experimental models, Tectonophysics, 522-523, 55-88.

Bos, A.G., Spakman, W. \& Nyst, M.C.J., 2003. Surface deformation and tectonic setting of Taiwan inferred from a GPS velocity field, J. geophys. Res., 108, 1-18.

Briais, A., Patriat, P. \& Tapponnier, P., 1993. Updated interpretation of magnetic anomalies and seafloor spreading stages in the south China Sea: implications for the tertiary tectonics of Southeast Asia, J. geophys. Res., 98, 6299-6328.

Brocher, T.M., 2005. Empirical relations between elastic wavespeeds and density in the earth's crust, Bull. Semol. Soc. Am., 95, 2081-2092.
Brown, D., Alvarez-Marron, J., Schimmel, M., Wu, Y.-M. \& Camanni, G., 2012. The structure and kinematics of the central Taiwan mountain belt derived from geological and seismicity data, Tectonics, 31, 1-25.

Brown, D., Alvarez-Marron, J., Biete, C., Kuo-Chen, H., Camanni, G. \& Ho, C.-W., 2017. How the structural architecture of the Eurasian continental margin affects the structure, seismicity, and topography of the south central Taiwan fold-and-thrust belt, Tectonics, 36, doi: 10.1002/2017TC004475.

Butler, R.W.H., Tavarnelli, E. \& Grasso, M., 2006. Structural inheritance in mountain belts: An Alpine-Apennine perspective, J. Struct. Geol., 28, 1893-1908.

Camanni, G., Brown, D., Alvarez-Marron, J., Wu, Y.-M. \& Chen, H.-A., 2014. The Shuilikeng fault in the central Taiwan mountain belt, J. Geol. Soc. Lond., 171, 117-130.

Camanni, G., Alvarez-Marron, J., Brown, D., Ayala, C., Wu, Y.-M. \& Hsieh, H.-H., 2016. The deep structure of south-central Taiwan illuminated by seismic tomography and earthquake hypocenter data, Tectonophysics, doi:10.1016/j.tecto.2015.09.016.

Cardozo, N. \& Allmendinger, R.W., 2009. SSPX: a program to compute strain from displacement/velocity data, Comput. Geosci., 35, 1343-1357.

Carena, S., Suppe, J. \& Kao, H., 2002. Active detachment of Taiwan illuminated by small earthquakes and its control of first-order topography, Geology, 30, 935-938.

Célérier, B., 1995. Tectonic regime and slip orientation of reactivated faults, Geophys. J. Int., 121, 143-161.

Célérier, B., 2008. Seeking Aderson's faulting in seismicity: A centennial celebration, Rev. Geophys., 46, 1-34.

Chang, C.-P., Chang, T.Y., Angelier, J., Kao, H., Lee, J.C. \& Yu, S.B., 2003. Strain and stress field in Taiwan oblique convergent system: Constraints from GPS observation and tectonic data, Earth planet. Sci. Lett., 214, $115-127$.

Chen, C.-H., 2000. Geological map of Taiwan, scale 1:500,000, Central Geological Survey, Taipei.

Chen, S.K., Wu, Y.-M., Hsu, Y.J. \& Chan, Y.C., 2017. Current crustal deformation of the Taiwan orogen reassessed by cGPS strain-rate estimation and focal mechanism stress inversion, Geophys. J. Int., 210, 228-239.

Chen, W. \& Molnar, P., 1983. Focal depth of intracontinental and intraplate earthquakes and their implications for thermal and mechanical properties of the lithosphere, J. geophys. Res., 88, 4183-4214.

Ching, K.E., Rau, R.J., Lee, J.C. \& Hu, J.C., 2007. Contemporary deformation of tectonic escape in SW Taiwan from GPS observations, 1995-2005, Earth planet. Sci. Lett., 262, 601-619.

Ching, K.E., Rau, R.J., Johnson, K.M., Lee, J.C. \& Hu, J.C., 2011. Presentday kinematics of active mountain building in Taiwan from GPS observations during 1995-2005, J. geophys. Res., 116, 1-22.

Chiu, H.T., 1975. Miocene stratigraphy and its relation to the Palaeogene rocks in West - Central Taiwan, Pet. Geol. Taiwan, 12, 51-80.

Ding, W., Li, J., Li, M., Qiu, X., Fang, Y. \& Tang, Y., 2008. A Cenozoic tectono-sedimentary model of the Tainan Basin, the South China Sea: evidence from a multi-channel seismic profile, J. Zhejiang Univ. A, 9, 702-713.

Erslev, E.A., 1993. Thrusts, back-thrusts, and detachment of rocky mountain foreland arches, in Laramide basement deformation in the rocky mountains foreland of the western United States: Boulder, Colorado, pp. 339-358, doi:10.1130/SPE280-p339.

Gölke, M. \& Coblentz, D., 1996. Origins of the European regional stress field, Tectonophysics, 266, 11-24.

Hardebeck, J.L. \& Hauksson, E., 2001. Crustal stress field in southern California and its implications for fault mechanics, J. geophys. Res., 106, $21859-21882$.

Hardebeck, J.L. \& Michael, A.J., 2004. Stress orientations at intermediate angles to the San Andreas Fault, California, J. geophys. Res. 109, B11303, doi:10.1029/2004JB003239.

Hardebeck, J.L. \& Okada, T., 2018. Temporal stress changes caused by earthquakes: a review, J. geophys. Res., 123, 1350-1365.

Hensch, M., Lund, B., Árnadóttir, Th. \& Brandsdóttir, B., 2016. Temporal stress changes associated with the 2008 May $29 M_{\mathrm{w}} 6$ earthquake doublet 
in the western South Iceland Seismic Zone, Geophys. J. Int., 204, 544554.

Ho, C.S., 1988. An introduction to the geology of Taiwan: explanatory text of the Geological Map of Taiwan, Central Geol. Sur., Taipei, Taiwan.

Homberg, C., Bergerat, F., Philippe, Y., Lacombe, O. \& Angelier, J., 2002. Structural inheritance and Cenozoic stress fields in the Jura fold-andthrust belt (France), Tectonophysics, 357, 137-158.

Hsu, S.K., Sibuet, J.C. \& Shyu, C.T., 2001. Magnetic inversion in the East China Sea and Okinawa Trough: tectonic implications, Tectonophysics, 333, 111-122.

Hsu, Y.J., Yu, S.B., Simons, M., Kuo, L.C. \& Chen, H.Y., 2009. Interseismic crustal deformation in the Taiwan plate boundary zone revealed by GPS observations, seismicity, and earthquake focal mechanisms, Tectonophysics, 479, 4-18.

Hsu, Y.J., Yu, S.B., Kuo, L.C., Tsai, Y.C. \& Chen, H.Y., 2011. Coseismic deformation of the 2010 Jiashian, Taiwan earthquake and implications for fault activities in southwestern Taiwan, Tectonophysics, 502, 328-335.

Hu, J. \& Angelier, J., 1996. Modeling of stress-deformation relationships in a collision belt: Taiwan, Terr. Atmos. Ocean. Sci., 7, 447-465.

Hu, J.C., Angelier, J. \& Yu, S.B., 1997. An interpretation of the active deformation of southern Taiwan based on numerical simulation and GPS studies, Tectonophysics, 274, 145-169.

$\mathrm{Hu}$, J.C. et al., 2007. Fault activity and lateral extrusion inferred from velocity field revealed by GPS measurements in the Pingtung area of southwestern Taiwan, J. Asian Earth Sci., 31, 287-302.

Huang, C. \& Byrne, T.B., 2014. Tectonic evolution of an active tectonostratigraphic boundary in accretionary wedge: An example from the Tulungwan-Chaochou Fault system, southern Taiwan, J. Struct. Geol., 69, 320-333.

Huang, C.Y., Yen, Y., Zhao, Q.H. \& Lin, C.T., 2012. Cenozoic stratigraphy of Taiwan: Window into rifting, stratigraphy and paleoceanography of South China Sea, Chin. Sci. Bull., 57, 3130-3149.

Jackson, J.A., 1980. Reactivation of basement faults and crustal shortening in orogenic belts, Nature, 283, 343-346.

Jahn, B.-M., Chi, W.R. \& Yui, T.F., 1992. A late Permian formation of Taiwan (marbles from Chia-Li well no.1) $\mathrm{Pb}-\mathrm{Pb}$ isochron and $\mathrm{Sr}$ isotopic evidence, and its regional geological significance, J. Geol. Soc. China, 35, 193-218.

Kagan, Y.Y., 2005. Double-couple earthquake focal mechanism: random rotation and display, Geophys. J. Int., 163, 1065-1072.

Kelly, P.G., Peacock, D.C.P., Sanderson, D.J. \& McGurk, A.C., 1999. Selective reverse-reactivation of normal faults, and deformation around reversereactivated faults in the Mesozoic of the Somerset coast, J. Struct. Geol., 21, 493-509.

King, R.C., Hillis, R.R., Tingay, M.R.P. \& Morley, C.K., 2009. Presentday stress and neotectonic provinces of the Baram Delta and deep-water fold-thrust belt, J. Geol. Soc. Lond., 166, 197-200.

Kuo-Chen, H., Wu, F.T. \& Roecker, S.W., 2012. Three-dimensional P velocity structures of the lithosphere beneath Taiwan from the analysis of TAIGER and related seismic data sets, J. geophys. Res., 117, 1-19.

Kuo-Chen, H., Wu, F., Chang, W.L., Chang, C.Y., Cheng, C.Y. \& Hirata, N., 2015. Is the Lishan fault of Taiwan active?, Tectonophysics, 661, 210-214.

Lacombe, O. \& Bellahsen, M., 2016. Thick-skinned tectonics and basementinvolved fold-thrust belts: insights from selected Cenozoic orogens, Geol. Mag., 153, doi:10.1017/S0016756816000078.

Lacombe, O., Mouthereau, F., Deffontaines, B., Angelier, J., Chu, H.T. \& Lee, C.T., 1999. Geometry and quaternary kinematics of fold-and-thrust units of southwestern Taiwan, Tectonics, 18, 1198-1223.

Lacombe, O., Mouthereau, F., Kargar, S. \& Meyer, B., 2006. Late Cenozoic and modern stress fields in the western Fars (Iran): implications for the tectonic and kinematic evolution of central Zagros, Tectonics, 25, 1-27.

Lan, C.Y., Lee, C.S., Yui, T.F., Chu, H.T. \& Jahn, B.M., 2008. The tectonothermal events of Taiwan and their relationship with SE China, Terr. Atmos. Ocean. Sci., 19, 257-278.

Leclère, H. \& Fabbri, O., 2013. A new three-dimensional method of fault reactivation analysis, J. Struct. Geol., 48, 153-161

Lester, R., Avendonk, H.J.a. Van, Mcintosh, K., Lavier, L., Liu, C.-S., Wang, T.K. \& Wu, F., 2014. Rifting and magmatism in the northeastern South
China Sea from wide-angle tomography and seismic reflection imaging, J. geophys. Res., 119, 2305-2323.

Letouzey, J., 1990. Fault reactivation, inversion and fold-thrust belt, in Petroleum and Tectonics in Mobile Belts, pp. 101-128, ed. Letouzey, J., Technip.

Li, C.F., Zhou, Z., Li, J., Hao, H. \& Geng, J., 2007. Structures of the northeastern most South China Sea continental margin and ocean basin: geophysical constraints and tectonic implications, Mar. Geophys. Res., 28, 59-79.

Lin, A.T. \& Watts, A.B., 2002. Origin of the West Taiwan basin by orogenic loading and flexure of a rifted continental margin, J. geophys. Res., 107, 2185.

Lin, A.T., Watts, A.B. \& Hesselbo, S.P., 2003. Cenozoic stratigraphy and subsidence history of the South China Sea margin in the Taiwan region, Basin Res., 15, 453-478.

Lin, A.T. et al., 2008. Tectonic features associated with the overriding of an accretionary wedge on top of a rifted continental margin: an example from Taiwan, Mar. Geol., 255, 186-203.

Lin, C.-W. \& Huang, M.-L., 1998. Influence of the Peikang Basement high on the structure development of the Western Foothills and Coastal Plain in south central Taiwan: a sandbox approach, Pet. Geol. Taiwan, 32, 105-122

Lund, B. \& Slunga, R., 1999. Stress tensor inversion using detailed microearthquake information and stability constraints : application to Ölfus southwest Iceland, J. geophys. Res., 104, 14 947-14 964.

Lund, B. \& Townend, J., 2007. Calculating horizontal stress orientations with full or partial knowledge of the tectonic stress tensor, Geophys. J. Int., 170, 1328-1335.

Macedo, J. \& Marshak, S., 1999. Controls on the geometry of fold-thrust belt salients, Bull. geol. Soc. Am., 111, 1808-1822.

Marshak, S., 2004. Salients, recesses, arcs, oroclines, and syntaxes-a review of ideas concerning the formation of map-view curves in fold-thrust belts, ed. ,McClay, K.R., in Thrust Tectonics and Hydrocarbon Systems, Vol. 82, pp. 131-156, AAPG Memoir, American Association of Petroleum Geologists.

McIntosh, K., Lavier, L., Avendonk, H. van, Lester, R., Eakin, D. \& Liu, C.S., 2014. Crustal structure and inferred rifting processes in the northeast South China Sea, Mar. Pet. Geol., 58, 612-626.

McKenzie, D.P., 1969. The relation between fault plane solutions for earthquakes and the directions of the principal stresses, Bull. seism. Soc. Am., 59, 591-601.

Michael, A., 1987. Use of focal mechanisms to determine stress: a control study, J. geophys. Res., 92, 357-368.

Mohn, G., Manatschal, G., Beltrando, M., Masini, E. \& Kusznir, N., 2012. Necking of continental crust in magma-poor rifted margins: evidence from the fossil Alpine Tethys margins, Tectonics, 31, 1-28.

Mouthereau, F. \& Lacombe, O., 2006. Inversion of the Paleogene Chinese continental margin and thick-skinned deformation in the Western Foreland of Taiwan, J. Struct. Geol., 28, 1977-1993.

Oncken, O., 1988. Aspects of the reconstruction of the stress history of a fold and thrust belt (Rhenish-Massif, Federal-Republic-of-Germany), Tectonophysics, 152, 19-40.

Peyret, M., Dominguez, S., Cattin, R., Champenois, J., Leroy, M. \& Zajac, A., 2011. Present-day interseismic surface deformation along the Longitudinal Valley, eastern Taiwan, from a PS-InSAR analysis of the ERS satellite archives, J. geophys. Res., 116, 1-21.

Poblet, J. \& Lisle, R.J., 2011. Kinematic evolution and structural styles of fold-and-thrust belts, Geol. Soc. Lond., Spec. Publ., 349, 1-24.

Richard, P. \& Krantz, R.W., 1991. Experiments on fault reactivation in strike slip mode, Tectonophysics, 188, 117-131.

Richardson, R.M., 1992. Ridge forces, absolute plate motions, and the intraplate stress field, J. geophys. Res., 97, 11 739-11 748.

Rodgers, J., 1990. Fold-and-thrust belts in sedimentary rocks; Part 1, Typical examples, Am. J. Sci., 290, 321-359.

Rodriguez-Roa, F.A. \& Wiltschko, D.V., 2010. Thrust belt architecture of the central and southern Western Foothills of Taiwan, Geol. Soc. Lond., Spec. Publ., 348, 137-168. 
Saintot, A. \& Angelier, J., 2002. Tectonic paleostress fields and structural evolution of the NW-Caucasus fold-and-thrust belt from Late Cretaceous to Quaternary, Tectonophysics, 357, 1-31.

Shaw, C.-L., 1996. Stratigraphic correlation and isopach maps of the western Taiwan Basin, Terr. Atmos. Ocean. Sci., 7, 333-360.

Sibson, R.H., 1983. Continental fault structure and the shallow earthquake source, J. geol. Soc. Lond., 140, 741-767.

Sibson, R.H., 1985. A note on fault reactivation, J. Struct. Geol., 7, 3-6.

Sibson, R.H., 1990. Conditions for fault-valve behaviour, Geol. Soc. Lond., Spec. Publ., 54, 15-28.

Sibson, R.H., 1994. Crustal stress, faulting and fluid flow, Geol. Soc. Lond., Spec. Publ., 78, 69-84.

Suppe, J., 1995. Present-day stress directions in Western Taiwan inferred from borehole elongation, Pet. Geol. Taiwan, 21, 1-12.

Tang, C.C., Zhu, L., Chen, C.H. \& Teng, T.L., 2011. Significant crustal structural variation across the Chaochou Fault, southern Taiwan: new tectonic implications for convergent plate boundary, J. Asian Earth Sci., 41, 564-570.

Tavani, S., Storti, F., Lacombe, O., Corradetti, A., Muñoz, J.A. \& Mazzoli, S., 2015. A review of deformation pattern templates in foreland basin systems and fold-and-thrust belts: implications for the state of stress in the frontal regions of thrust wedges, Earth-Sci. Rev., 141, 82-104.

Teng, L.S., 1992. Geotectonic evolution of the Tertiary continental margin basins of Taiwan, Pet. Geol. Taiwan, 27, 1-19.

Teng, L.S. \& Lin, A.T., 2004. Cenozoic tectonics of the China continental margin: insights from Taiwan, Geol. Soc. London, Spec. Publ., 226, $313-$ 332

Tingay, M., Müller, B., Reinecker, J., Heidbach, O., Wenzel, F. \& Fleckenstein, P., 2005. Understanding tectonic stress in the oil patch: The World Stress Map Project, Lead. Edge, 24, 1276-1282.

Townend, J. \& Zoback, M.D., 2006. Stress, strain, and mountain building in central Japan, J. geophys. Res., 111, B03411, doi:10.1029/2005JB003759.

Townend, J., Sherburn, S., Arnold, R., Boese, C. \& Woods, L., 2012. Threedimensional variations in present-day tectonic stress along the AustraliaPacific plate boundary in New Zealand, Earth planet. Sci. Lett., 353-354, 47-59.

Turner, J.P. \& Williams, G.A., 2004. Sedimentary basin inversion and intraplate shortening, Earth-Sci. Rev., 65, 277-304.

Twiss, R.J. \& Moores, E.M., 1992. Structural Geology, W.H. Freeman and Company, p. 532.

Vavrycuk, V., 2014. Iterative joint inversion for stress and fault orientations from focal mechanisms, Geophys. J. Int., 199, 69-77.

Waldhauser, F., 2001. hypoDD - a program to compute doubledifference hypocenter locations, U.S. Geol. Surv. Open File Rep., 1-25, doi: $10.3133 /$ ofr01113

Waldhauser, F. \& Ellsworth, W.L., 2000. A double-difference earthquake location algorithm: method and application to the Northern Hayward Fault, California, Bull. seism. Soc. Am., 90, 1353-1368.

Wang, C.-Y., Chang, C.-H. \& Yen, H.-Y., 2000. An interpretation of the 1999 Chi-Chi earthquake on the thin-skinned thrust model, Terr. Atmos. Ocean. Sci., 11, 609-630.

Wessel, P. \& Smith, W.H.F., 1998. New, improved version of generic mapping tools released, EOS, Trans. Am. geophys. Un., 79(47), 579.

Wiltschko, D. \& Eastman, D., 1983. Role of basement warps and faults in localizing thrust fault ramps, in Geological Society of America, pp. 177-190. doi:10.1130/MEM158-p177.

Wiltschko, D. V., Hassler, L., Hung, J.-H. \& Liao, H.-S., 2010. From accretion to collision: motion and evolution of the Chaochou Fault, southern Taiwan, Tectonics, 29, 1-23.

Wu, J., Suppe, J., Lu, R. \& Kanda, R., 2016. Philippine Sea and East Asian plate tectonics since 52 Ma constrained by new subducted slab reconstruction methods, J. geophys. Res., 121, 4670-4741.

Wu, S.K., Chi, W.C., Hsu, S.M., Ke, C.C. \& Wang, Y., 2013. Shallow crustal thermal structures of central Taiwan foothills region, Terr. Atmos. Ocean. Sci., 24, 695-707.

Wu, Y.-M., Zhao, L., Chang, C.-H. \& Hsu, Y.J., 2008. Focal-mechanism determination in Taiwan by genetic algorithm, Bull. seism. Soc. Am., 98, 651-661.
Wu, Y.-M., Hsu, Y.-J., Chang, C.-H., Teng, L.S. \& Nakamura, M., 2010. Temporal and spatial variation of stress field in Taiwan from 1991 to 2007: insights from comprehensive first motion focal mechanism catalog, Earth planet. Sci. Lett., 298, 306-316.

Yang, K.-M., Ting, H.-H. \& Yuan, J., 1991. Structural styles and tectonic modes of Neogene extensional tectonics in southwestern Taiwan: implications for hydrocarbon exploration, Pet. Geol. Taiwan, 26, 1-31.

Yang, K.-M., Rau, R.-J., Chang, H.-Y., Hsieh, C.-Y., Ting, H.-H., Huang, S.T., Wu, J.-C. \& Tang, Y.-J., 2016. The role of basement-involved normal faults in the recent tectonics of western Taiwan, Geol. Mag., 153, 11661191.

Yeh, Y.C., Hsu, S.K., Doo, W. Bin, Sibuet, J.C., Liu, C.S. \& Lee, C.S., 2012. Crustal features of the northeastern South China Sea: Insights from seismic and magnetic interpretations, Mar. Geophys. Res., 33, 307-326.

Yu, S., Chen, H. \& Kuo, L., 1997. Velocity field of GPS stations in the Taiwan area, Tectonophysics, 274, 41-59.

Yue, L.-F., Suppe, J. \& Hung, J.-H., 2005. Structural geology of a classic thrust belt earth- quake: the 1999 Chi-Chi earthquake Taiwan $\left(M_{\mathrm{W}}=7.6\right)$, J. Struct. Geol., 27(11), 2058-2083.

Zoback, M.L., 1992. First- and second-order patterns of stress in the lithosphere: the World stress map project, J. geophys. Res., 97, 11 703-11 728 .

Zoback, M.L. et al., 1989. Global patterns of tectonic stress, Nature, 341, 291-298.

\section{SUPPORTING INFORMATION}

Supplementary data are available at $G J I$ online.

Figure S1. Focal mechanism cluster information and results from the inversion for each depth level cluster of Fig. 5. For each cluster there are seven plots which in order from left to right show (all steronets are equal area lower hemisphere plots): three plots with the focal mechanism information-Column (A): stereonets with $P$ and $T$-axes. Column (B): stereonets with poles to the nodal planes. Column (C): triangular distribution plot depending on the faulting type after Kagan (2005) - and four plots with the results of the inversion. Column (D): best-fitting stress tensor, with $\sigma_{1}, \sigma_{2}$ and $\sigma_{3}$ directions (symbols: square, diamond, triangle, respectively) and the 10,68 and 95 per cent confidence limits of $\sigma_{1}$ and $\sigma_{3}$ coloured, in warm and cold colours, respectively. At the edge of the plot is the $S_{\mathrm{H}}$ direction with its confidence limit as a histogram. Column (E): stereonets showing the Kamb contours of the poles to the selected fault planes that best fit the stress tensor. Column (F): Rose diagram with the strikes of the selected fault planes from Column (D), highlighting the mean strike of the primary and secondary fault families in red solid and dashed lines, respectively. Column (G): Mohr-Coulomb diagrams with all nodal planes in the clusters, showing with red circles the selected nodal planes and with blue crosses the nodal planes that were not selected. A coefficient of friction of 0.6 was used to construct the Mohr-Coulomb diagrams. Parameters of the inversion results: $N$, number of events; $R$, relative size of the intermediate principal stress; Dev, deviation; Mis, misfit. The locations of the clusters are shown in Fig. 5.

Table S1. Table of the 2456 earthquake focal mechanism data sets used in this study with their occurrence time (year, month, day, minute, and second); location (lat., long and depth); local Magnitude $\left(M_{\mathrm{L}}\right)$; strike, dip and rake of the focal mechanisms solution; and the strike, dip and rake of standard deviation (str_sdv, dip_sdv, rake_sdv, respectively). Also provided are the number of polarity readings (Npor), the azimuthal gap (Gap), the relative measure of up to down polarity readings (Rup) and the quality index (Qfp) following $\mathrm{Wu}$ et al. (2008). The trend and plunge of $P$-, $T$ - and $B$-axes are also provided. Finally, the cluster to which each event belongs is also 
given. If the event is not used in any cluster it is indicated by asign. The locations of the clusters are shown in Fig. 5.

Table S2. Table with clusters' statistics values (median, average, one standard deviation) for the focal mechanism solution quality index (Qfp) given by Wu et al. (2008). The number of events in each cluster with Qfp below 0.2 (N_Qfp $<0.2)$ and its percentage (per cent_Qfp $<0.2$ ) are also shown. The number of nodal planes chosen with the instability criterion in each cluster (InstaPlane), along with its percentage (per cent_InstaPlane), is also shown. The median, average and standard deviation of each column are given at the bottom of the table.

Please note: Oxford University Press is not responsible for the content or functionality of any supporting materials supplied by the authors. Any queries (other than missing material) should be directed to the corresponding author for the paper. 